\title{
Linkages between Climate Change and Coastal Tourism: A Bibliometric Analysis
}

\author{
Vyddiyaratnam Pathmanandakumar ${ }^{1}\left[\right.$ (D) Sheeba Nettukandy Chenoli ${ }^{1, *}$ and Hong Ching Goh ${ }^{2}(\mathbb{D})$ \\ 1 Department of Geography, Faculty of Arts and Social Sciences, Universiti Malaya, \\ Kuala Lumpur 50603, Malaysia; pathmanandakumarv@esn.ac.lk \\ 2 Department of Urban \& Regional Planning, Faculty of Built Environment, Universiti Malaya, \\ Kuala Lumpur 50603, Malaysia; gohhc@um.edu.my \\ * Correspondence: sheeba@um.edu.my; Tel.: +603-79675529
}

Citation: Pathmanandakumar, V.; Chenoli, S.N.; Goh, H.C. Linkages between Climate Change and Coastal Tourism: A Bibliometric Analysis. Sustainability 2021, 13, 10830. https:// doi.org/10.3390/su131910830

Academic Editor: Pablo Peri

Received: 4 August 2021

Accepted: 24 September 2021

Published: 29 September 2021

Publisher's Note: MDPI stays neutral with regard to jurisdictional claims in published maps and institutional affiliations.

Copyright: (c) 2021 by the authors. Licensee MDPI, Basel, Switzerland. This article is an open access article distributed under the terms and conditions of the Creative Commons Attribution (CC BY) license (https:// creativecommons.org/licenses/by/ $4.0 /)$.

\begin{abstract}
Tourism and climate are inextricably linked to several interactions. In recent years, there has been a greater focus on the linkages between climate change and coastal tourism. This study aims to provide an overview of the literature on climate change and coastal tourism, identify core areas of interest and important sources and authors, and examine the thematic evolution of the field. A bibliometric analysis of 92 documents related to climate change and coastal tourism published in the Web of Science Core Collection database was carried out. The analysis provides information on the most cited papers, most leading authors, the most productive countries, and the most leading institutions in this field. The study utilized the Visualization of Similarities Viewer program (VOS) to map author keyword co-occurrences, co-citations, and bibliographic coupling. The study showed that, with some fluctuations since 2008, the number of publications in this field had increased significantly. The most influential authors and most productive institutions are from the United States of America, England, Canada, and other European countries. The findings of this study will assist researchers conducting climate change and coastal tourism-related studies to understand which papers, academics, organizations, countries, and journals have a dominant influence on climate change and coastal tourism research.
\end{abstract}

Keywords: bibliometric analysis; climate change; co-citation; coastal tourism; visualization; VOS viewer

\section{Introduction}

Scientific studies on climate change and tourism have expanded for more than 25 years since the first scientific paper was published in 1986 [1]. However, awareness of climate change effects on tourism has been sluggish over the next decade. Also, tourism was not mentioned in the IPCC First Assessment Report (1990) of the United Nations. Tourism received better coverage in the Second Assessment Report of the IPCC (1995) [2]. However, the question of how climate change will affect tourism in the future was not well addressed [3]. Scientific studies relevant to climate change and tourism have risen substantially towards the end of the 1990s. Publications related to climate change and coastal tourism increased considerably between 1995 and 2004 [4]. The relationship between tourism and climate is very intricate, with multiple interactions. The major part of emissions from the tourism sector comes from the greenhouse gas emissions through tourists' transportation and accommodation [5,6]. The carbon footprint of the global tourism industry has increased by $15 \%$ from 3.9 to 4.5 gigatons (Gt) of equivalent carbon dioxide, accounting for about $8 \%$ of global greenhouse gas emissions, and it is estimated that global tourism will increase carbon emissions by about $6.5 \mathrm{Gt}$ by 2025 [7]. According to a landmark new report from the World Tourism Organization (UNWTO) and the International Transport Forum (ITF), tourism transportation emissions are predicted to account for $5.3 \%$ 
of all human-made $\mathrm{CO}_{2}$ emissions by 2030 when compared to the $5 \%$ in 2016 [6]. Nevertheless, tourism can promote the conservation of natural resources and reforestation to mitigate climate change [8]. The condition of the climate is one of the co-determiners of the suitability of the location; thereby, climate change becomes a pivotal factor in the tourism experience [9,10], shaping the future of tourism [11-13].

Hall (2001) stated that ocean and marine environments are among the most critical resources for the tourism market [14], where coastal tourism has become the fastest-growing industry and has reached its peak in the last two decades, becoming one of the world's largest industries [4,14-16]. Comfortable weather and climate conditions are essential for coastal tourism [17-21] and require an optimum environmental feature for sun, sand, and sea (3S) tourism [22]. The impact of climate change will have an impact on tourism, namely in coastal and mountain locations [23]. Coastal tourism is very sensitive to the impacts of climate change, which include a rise in sea level, changes in sea surface temperature, increased storm frequency and intensity, ocean acidification, and deoxygenation [24-26]. The observation shows that climate change occurs earlier and faster than scientists predicted [27-30]. Tourism's price structure, revenue, and perceived quality of the destinations are jeopardized when the $3 S$ (Sun, Sand, Sea) become the 2 S (Sun, Sea) [31]. Therefore, understanding the ties between climate change and coastal tourism is important for policymakers, tourism leaders, and local stakeholders. Addressing climate change issues is one of the top concerns of the tourism industry. Over the years, the number of relevant literature is on an increase in this regard. Several studies have attempted to profile research on climate change and tourism, covering a wide range of topics (Table 1).

Table 1. Examples of topics covered in climate change and tourism literature between 2005 and 2020.

\begin{tabular}{|c|c|c|c|}
\hline Article Title & Document Types & Authors & References \\
\hline Effects of climate change on international tourism & Research article & $\begin{array}{l}\text { Jacqueline M. Hamilton, David J. Maddison, } \\
\text { Richard S. J. Tol }\end{array}$ & [32] \\
\hline Weather, climate, and tourism & Research article & Ma Belen Gomez Martın & [33] \\
\hline Implications of global climate change for tourism & Research article & Bas Amelung, Sarah Nicholls, David Viner & [34] \\
\hline $\begin{array}{l}\text { Climate change and tourism-responding to global } \\
\text { challenges }\end{array}$ & Report & UNWTO, UNEP & {$[8]$} \\
\hline Climate change vulnerability assessment & Research article & Alvaro Moreno, Susanne Becken & [35] \\
\hline Tourists' perceptions in a climate of change & Research article & $\begin{array}{l}\text { Christine N. Buzinde, David Manuel-Navarrete, } \\
\text { Eunice Eunjung Yoo, Duarte Morais }\end{array}$ & [36] \\
\hline International tourism and climate change & Review article & Daniel Scott, Stefan Gossling, C. Michael Hall & [37] \\
\hline $\begin{array}{l}\text { Tourism and climate change: Impacts, Adaptation and } \\
\text { Mitigation }\end{array}$ & Book & Daniel Scott, Stefan Gossling, C. Michael Hall & [25] \\
\hline $\begin{array}{l}\text { Consumer behaviour and demand response of tourists } \\
\text { to climate change }\end{array}$ & Research article & $\begin{array}{l}\text { Stefan Gossling, Daniel Scott, C. Michael Hall, } \\
\text { Jean-Paul Ceron, Ghislain Dubois }\end{array}$ & [38] \\
\hline $\begin{array}{l}\text { Differential climate preferences of international beach } \\
\text { tourists }\end{array}$ & Research article & Michelle Rutty, Daniel Scott & [19] \\
\hline Climate change and tourism & Book chapter & Peter Burns, L & [39] \\
\hline Assessing the Costs of Climate Change and Adaptation & Report & Mahfuz Ahmed Suphachol Suphachalasai & [40] \\
\hline Climate Change Implications for Tourism & Book chapter & Daniel Scott & [41] \\
\hline Coastal and Ocean Tourism & Book chapter & Stefan Gossling, C. Michael Hall, Daniel Scott, & [42] \\
\hline Tourism under climate change scenarios & Research article & $\begin{array}{l}\text { Isabel Jurema Grimm, Liliane C. S. Alcântara, } \\
\text { Carlos Alberto Cioce Sampaio }\end{array}$ & [9] \\
\hline Global cl & Bool & J. Buultjens, I. Ratnayake, W.K. Gnanapala Athula & [43] \\
\hline Global tourism vulnerability to climate change & Research article & Daniel Scott, C. Michael Hall, Stefan Gossling, & [44] \\
\hline The market for climate services in the tourism sector & Book chapter & $\begin{array}{l}\text { Judith Köberla, Peter Stegmaierb, Elisa Jiménez } \\
\text { Alonsoc, Atte Harjanned }\end{array}$ & {$[13]$} \\
\hline
\end{tabular}

While many publications are available on climate change and tourism [45], there has been limited investigation on reviewing current understandings to discover the knowledge gap so as to embark on new studies of climate change and coastal tourism. Several publications on climate change and coastal tourism emerged in recent years, indicating a growing interest in the subject. Few bibliometric analyses have been carried out emphasising climate change and coastal regions, coastal communities, or tourism in general (For example: [45-47]). However, to the best of our knowledge, no attempt has been made to conduct a systematic bibliometric analysis of the rapidly expanding climate change 
and coastal tourism literature. A bibliometric study on this topic is therefore still limited. Despite the fact that there is a lack of bibliometric analysis in this field, this type of bibliometric study, combined with visualization analysis, is valuable for researchers. This bibliometric analysis provides an overview of climate change and coastal tourism and a visual representation of the structure, growth, and trends contributing to climate change and coastal tourism knowledge.

Furthermore, this paper can provide novel points that can help researchers organize their future research. Due to the relevance of the bibliometric analysis for literature in general and the absence of adequate bibliometric and visualization studies on climate change and coastal tourism, this paper aims to provide an overview of the literature on climate change and coastal tourism, identify core areas of interest and important sources and authors, and examine the thematic evolution of the field. This paper is organized as follows: The introduction section (Section 1) empirically complements the typical literature reviews on climate change and coastal tourism with a personal opinion and interpretation. The materials and methods in Section 2 describe data collection using VOS viewer. Section 3 elaborates a comprehensive analysis of research outputs and their categories. Finally, the "Discussion and Conclusion" section summarizes the key findings and suggests future research directions, demonstrating the broad applicability of this work.

\section{Materials and Methods}

Scopus, Web of Science, and Google Scholar are the most frequently viewed consistent databases and cover a wide range of scientific knowledge [46]. An ideal strategy would be to integrate all databases. Since each database has a unique structure, merging and filtering data for integrated analysis is not easy. As a result, choosing a single database is the optimum option for performing a bibliometric analysis [48]. However, it should also be emphasized that using a single database can never encompass all existing data; therefore, this strategy will always have limitations. For this study, documents indexed in WoS were used to select scientific data on climate change and coastal tourism.

In December 2020, analytical data was collected from the Web of Science (WoS) core collection database, considered the most influential database and consisting of more than 15,000 journals and 50,000,000 articles under 251 categories and 151 research areas [49,50]. It comprises several sub-databases, including the most influential journals with the highest standards [51]. The following factors were considered when constructing the search criteria: (A) tourism must be coastal tourism; (B) coastal tourism must be distinguished from other types of tourism; and $(C)$ the primary factors causing vulnerability must be linked to climate change. When using these requirements, Boolean operators and quote marks should be applied to avoid publications that include comparable phrases but lack the necessary semantic context [46]. As a result, in this study, the authors used the following keywords in the main search field of the WoS database to find all articles: "climate change" AND "coastal tourism". The topic search field included searches title, abstract, author keywords, and keywords plus (Indexes: SCI-EXPANDED, SSCI, A\&HCI, CPCI-S, CPCISSH, BKCI-S, BKCI-SSH, ESCI). The search criteria were refined by selecting documents written in the English language. Still, they were not refined by the timespan that produced a list of 92 documents (included: articles, proceedings papers, reviews, books, book chapters, book reviews, editorial materials, and early access) (Figure 1). This variety of documents provided us with more information than if we had only used one type of publication [51]. The relevant documents were collected from 1991 to 2020 since the "climate change and coastal tourism" database is available only from 1991.

However, the first document on climate change and coastal tourism was published in the WoS core collection in 1999, which can be considered a pioneer work in climate change and coastal tourism. Therefore, the period of this study is limited to 1999 to 2020 . All search data records have been exported to Tab-delimited (text file) with complete descriptions and cited references. The findings of the study were reconfirmed with the online tool "analysis results" from the WoS website. The visualization of co-citation analysis, keyword 
co-occurrences, and bibliographical coupling were performed using VOS viewer (1.6.14). In this study, we only utilized the WoS database; therefore, the possibilities of duplication and errors were minimal [52]. Furthermore, the Web of Science website's analysed results were used to confirm the research findings.
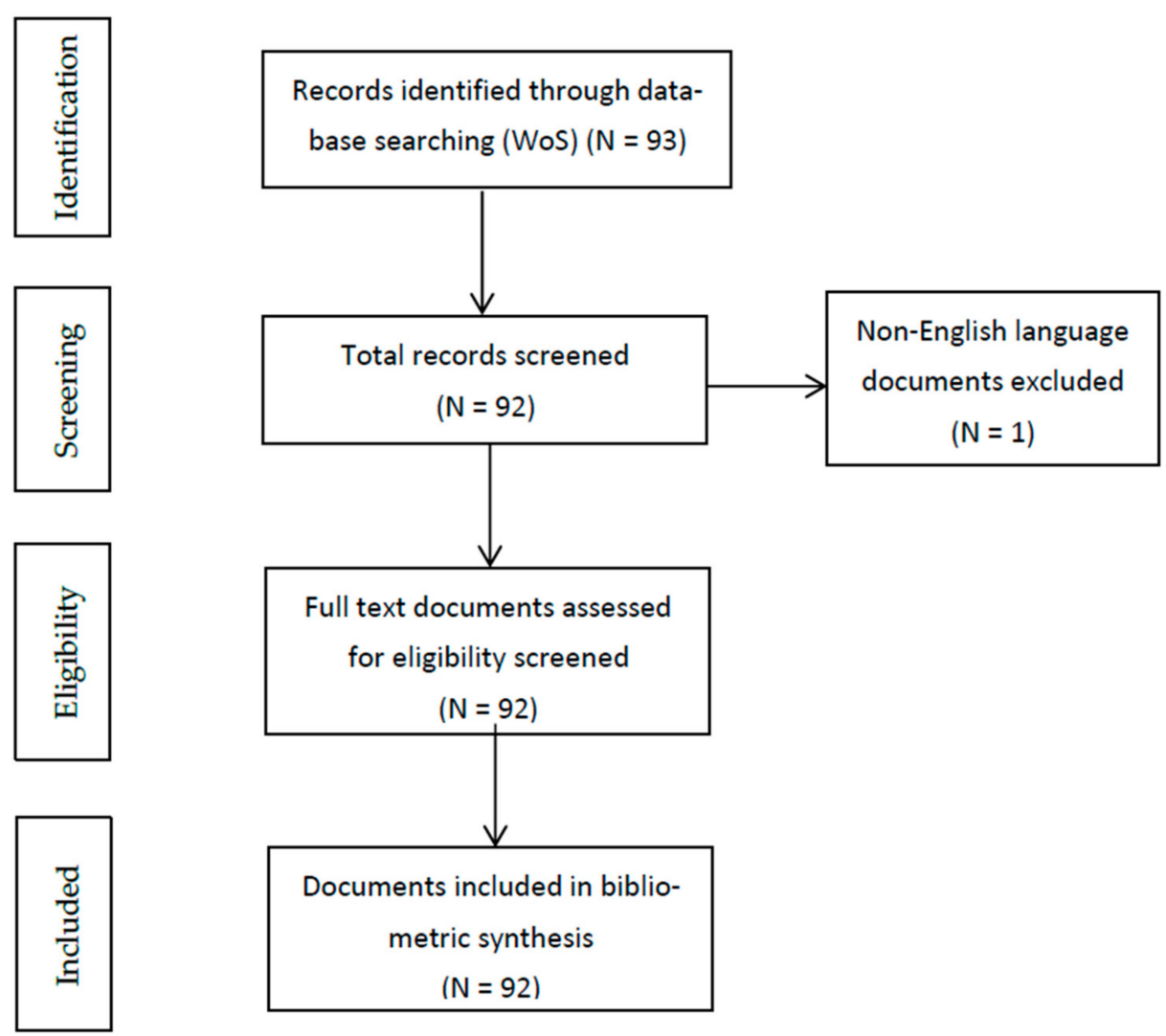

Figure 1. Preferred Reporting Items for Systematic reviews and Meta-Analyses (PRISMA) flow diagram [53] for the systematic review of climate change and coastal tourism.

Bibliometric analysis is a statistical research technique that can map the structure and pattern of evolving knowledge through the formal improvement of data repositories [54,55]. Bibliometric analysis is a quantitative method for describing, evaluating, and monitoring published research $[46,56]$. Bibliometric analysis can introduce a systemic, transparent, and reproducible review process, thereby enhancing the review's quality [57], as insisted by Cobo et al. [58]. Bibliometric analysis has two primary uses: performance analysis (evaluating the performance of research and publication of individuals and institutions) and science mapping (revealing the structure and dynamics of scientific fields) $[48,59,60]$. Bibliometric analysis enables a particular area to determine emerging trends and evolving knowledge. In addition, pioneering researchers and research lines of study in specific fields can be displayed using a bibliometric analysis that allows an analysis to be carried out in the current state of the science and the new research front [46]. The mapping of scientific literature based on the bibliometric method complements the meta-analysis and the structural analysis [61-64]. Initially, the bibliometric approach started to assess academic success based on the number of citations of a given author or organization [65]. At present, however, it is often used to explain the structure and pattern of growth of the different fields of knowledge [46]. The bibliometric approach offers a macro view compared to a structured literature review. It complements both the detailed analysis of literature and broader research [64]. The quantitative approach to the classification, assessment, and tracking of the published papers are used in the bibliometric review [59].

The analysis of parameters influences the study of the research area's various aspects $[49,50,59]$. The main bibliometric techniques (performance analysis and science 
mapping) were used as the analysis methods of this study. The authors' publications, names of the institutions, countries, and journals (to measure the productivity), citations (to measure total citations), co-citations (to measure the relationship between publications and most influential publications), bibliographic couplings (to analyse the relationship among cited publications and present themes) and keyword co-occurrences (to look into existing or future relationship among topics) were some of the most popular bibliometric indicators used in this study $[45,46,48-51,63,64]$ Co-citation analysis measures the number of times two papers are cited in the third paper [66]. Bibliographic coupling occurs when the two articles have cited the third article [67]. Finally, keyword co-occurrences analysis counts the most common keywords in the published articles [64]. The bibliometric indicators can also be used to assess the quantity and quality of publications. The publication's quantity and quality shall be determined by the number of articles published and the total number of citations obtained [64]. Also, it is possible to identify leading researchers and research lines in some areas using bibliometric analysis that provides an overview of the current state of the subject and the new field of research on the particular topic. This analytical approach encourages the autonomy of the researcher in interpreting data of interest. Additionally, a visual representation of the network topology (VOS viewer 1.6.16) is applied to understand the current status of the literature on climate change and coastal tourism [46].

Several methods are used to represent bibliometric data in this research. The number of publications and citations are considered the basis of the most common bibliometric techniques in which the number of publications and citations measures efficiency and influence, respectively [49]. Keyword analysis was carried out to explain the nature, connections, and concepts used by authors. Co-occurrences of keywords, co-citations, and bibliographic coupling were visualized using VOS viewer 1.6.16. Citation analysis was conducted to identify the most cited paper and the most influential author. In contrast, the organizations and country analyses were undertaken to highlight the leading institutions and countries that published scientific articles on climate change and coastal tourism. Both full and fractional counts were adapted in this analysis using the WoS database and VOS view software.

\section{Results}

The results of the bibliometric analysis are as follows: The first section is a summary of the quantitative results. The second portion examines the state and progress of climate change and coastal tourism literature. The third section focuses on the publications that other authors quote the most and the most prominent authors in terms of climate change and coastal tourism. The fourth part identifies the institutions with the most citations per paper and the countries with the highest productivity. Section five discusses keyword co-occurrences analysis. The sixth section discusses the co-citation analysis of cited authors and cited references. Finally, the study explores the country's bibliographic coupling.

\subsection{General Result}

The analysis identified 71 articles, 9 proceeding papers, 7 book chapters, and 5 book reviews. It amounted to 92 documents by 281 writers associated with 177 institutions in 41 countries and written in 59 source titles, citing 1766 references with an average citation of 9.2 per item (Table 2).

Table 2. The general results of bibliometric analysis.

\begin{tabular}{cc}
\hline Criteria & Quantity \\
\hline Documents & 92 \\
Author & 281 \\
Source title & 59 \\
Countries & 41 \\
Institutions & 177 \\
Cited references & 1766 \\
Average citation per item & 9.2 \\
\hline
\end{tabular}




\subsection{Trends and Patterns of "Climate Change and Coastal Tourism" Research in the Literature}

The number of papers published by an academic researcher significantly shows the strength and efficacy of the researcher. In addition, the number of publications published each year is an important indicator to assess the progress of a particular field of study [52]. Figure 2 depicts the number of documents on climate change and coastal tourism published in the WoS database each year. In 1999, the WoS core collection began publishing articles on climate change and coastal tourism as tourism received better coverage in the Second Assessment Report of the IPCC (1995). However, the future effects of climate change on tourism were not well addressed [3]. No published documents were found in the WoS core database between 2001 and 2003 and 2005 and 2007 under climate change and coastal tourism. It is possible to assume that this is due to the fact that the impact of tourism on climate change was not recognized in the IPCC Third Assessment Report (2001). However, regular publications on this topic started in 2008, with five publications in 2008 alone, because special attention was paid to climate change and tourism in the Regional Chapter of the IPCC Fourth Assessment (2007) [3]. Since then, with some exceptions in 2013, 2017 , and 2020, the publication number has gradually increased. The highest number of documents on climate change and coastal tourism was published in 2019 (12 publications), followed by 2016 (11 publications), and 2015 (10 publications). Despite the research output showing fluctuations from one year to the next, there has been a growing trend between 2007 and 2020 (Figure 2). It is important to note that 2020 had eight published documents until the 4th of December 2020.

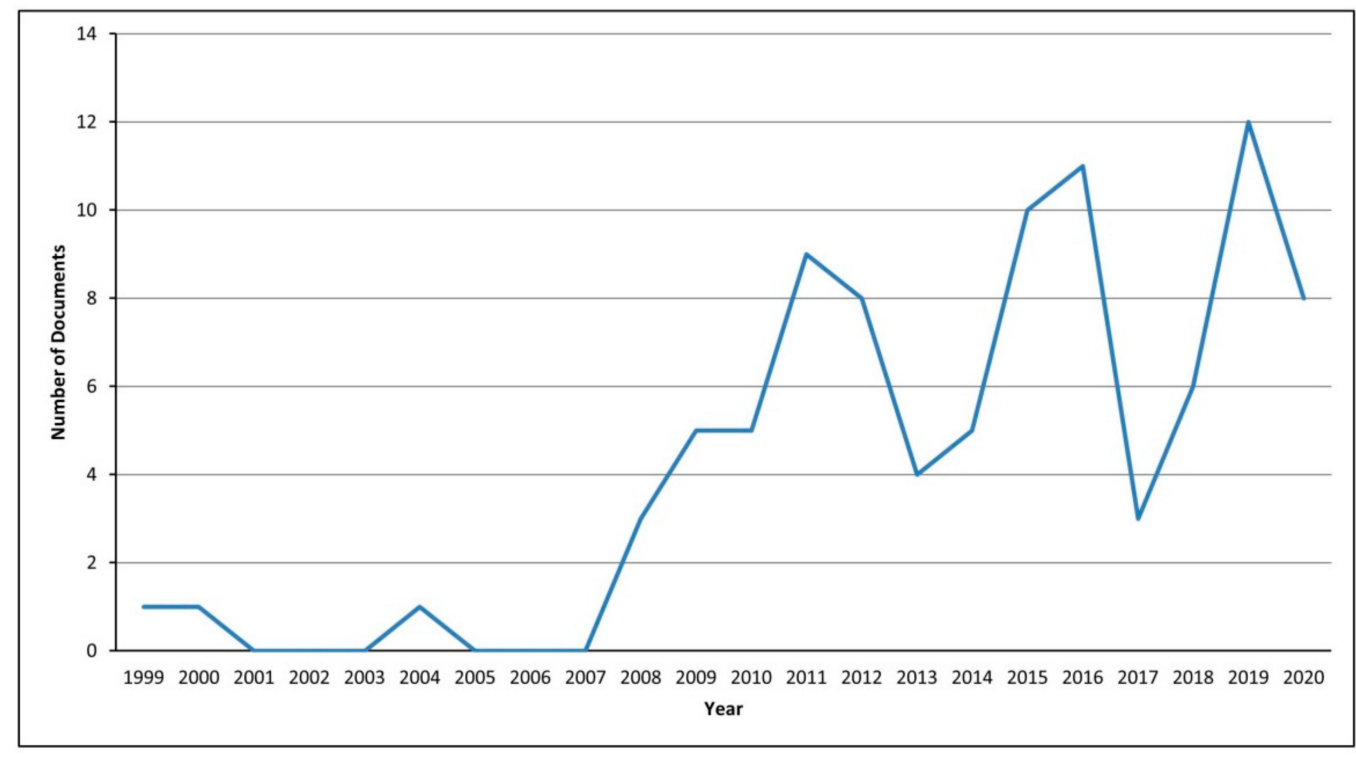

Figure 2. The annual number of documents published in WoS core collection.

\subsection{The Most Cited Paper and Influential Authors}

The analysis of the number of citations obtained by published articles shows the relevance of the document in the field $[45,46]$. The most frequently cited articles indicate their strong relevance as reference material. In general, the articles published earlier have had more time to be cited than the recent papers. The most cited papers are widely recognized as landmarks due to their pioneering contributions [68]. However, it should be remembered that the most cited articles are not necessarily the most important ones [50]. The following Table 3 shows the top ten most cited papers on climate change and coastal tourism. Katsanevakis et al. [69] wrote the article that received the most citations (220) and the most citations per year (22). This study discussed marine spatial management and sustainable development, including coastal tourism development. Najjar et al. [70] placed second in terms of citations (145) and sixth in terms of citations per year (6.9). This research investigated the potential impacts of climate change on the mid-Atlantic coastal 
(MAC) region of the United States. The paper that got the third rank in the number of citations (131) and second in the number of citations per year (14.5) was written by Scott, Hall et al. [37]. This article examined the vulnerability of Caribbean coastal tourism to scenarios of climate change-related sea-level rise. These studies were primarily concerned with three themes: climate change, coastal tourism, and impacts and vulnerabilities.

Table 3. The top ten most cited publications between 1999-2020.

\begin{tabular}{|c|c|c|c|c|c|c|}
\hline Rank & Authors & Title & $\begin{array}{l}\text { Document } \\
\text { Type }\end{array}$ & $\begin{array}{l}\text { Publication } \\
\text { Year }\end{array}$ & $\begin{array}{c}\text { Total } \\
\text { Citations }\end{array}$ & $\begin{array}{l}\text { Average } \\
\text { per Year }\end{array}$ \\
\hline 1 & Katsanevakis et al. [69] & $\begin{array}{l}\text { Ecosystem-based marine spatial } \\
\text { management: Review of concepts, policies, } \\
\text { tools, and critical issues }\end{array}$ & Review article & 2011 & 220 & 22 \\
\hline 2 & Najjar et al. [70] & $\begin{array}{l}\text { The potential impacts of climate change on } \\
\text { the mid-Atlantic coastal region }\end{array}$ & Research article & 2000 & 145 & 6.9 \\
\hline 3 & Scott, Hall et al. [37] & International tourism and climate change & Review article & 2012 & 131 & 14.5 \\
\hline 4 & Moreno \& Becken [35] & $\begin{array}{l}\text { A climate change vulnerability assessment } \\
\text { methodology for coastal tourism }\end{array}$ & Research article & 2009 & 120 & 10 \\
\hline 5 & Scott, Simpson, et al. [71] & $\begin{array}{l}\text { The vulnerability of Caribbean coastal } \\
\text { tourism to scenarios of climate } \\
\text { change-related sea-level rise }\end{array}$ & Research article & 2012 & 92 & 10.2 \\
\hline 6 & Rutty \& Scott [18] & $\begin{array}{l}\text { Bioclimatic comfort and the thermal } \\
\text { perceptions and preferences of beach } \\
\text { tourists }\end{array}$ & Research article & 2015 & 67 & 11.2 \\
\hline 7 & Kildow \& McIlgorm [72] & $\begin{array}{l}\text { The importance of estimating the } \\
\text { contribution of the oceans to national } \\
\text { economies }\end{array}$ & Research article & 2010 & 65 & 5.9 \\
\hline 8 & Calgaro \& Lloyd [73] & $\begin{array}{l}\text { Sun, sea, sand and tsunami: examining } \\
\text { disaster vulnerability in the tourism } \\
\text { community of Khao Lak, Thailand } \\
\text { Governing resilience building in }\end{array}$ & Research article & 2008 & 64 & 4.9 \\
\hline 9 & Larsen et al. [74] & $\begin{array}{l}\text { Thailand's tourism-dependent coastal } \\
\text { communities: Conceptualising stakeholder } \\
\text { agency in social-ecological systems }\end{array}$ & Research article & 2011 & 63 & 6.3 \\
\hline 10 & Buzinde et al. [36] & $\begin{array}{l}\text { Tourists' perceptions in a climate of change } \\
\text { eroding destinations }\end{array}$ & Research article & 2010 & 57 & 5.2 \\
\hline
\end{tabular}

Table 4 displays the top ten most influential authors by the highest number of publications and the highest citations. For example, Daniel Scott is the most influential author in climate change and coastal tourism research with 7 publications and 362 citations, despite holding third place in the most cited publication rankings (Table 3).

Table 4. The top ten leading authors based on the number of publications and the number of citations.

\begin{tabular}{ccccc}
\hline Author & No of Documents & No of Citations & Institutional Affiliation & Country \\
\hline Scott, Daniel & 7 & 362 & University of Waterloo & Canada \\
Becken, Susanne & 2 & 151 & Lincoln University & New Zealand \\
Gossling, Stefan & 3 & 144 & Linnaeus University & Sweden \\
Hall, C. Michael & 2 & 132 & University of Canterbury & New Zealand \\
Calgaro, Emma & 2 & 127 & Stockholm Environment Institute Asia & Thailand \\
Rutty, Michelle & 4 & 126 & University of Waterloo & Canada \\
Manuel-Navarrete, David & 2 & 100 & Kings College London & England \\
Buzinde, Christine N. & 2 & 100 & Pennsylvania State University & USA \\
Jones, Andy P. & 3 & 64 & University of East Anglia & England \\
Coombes, Emma G. & 3 & 64 & University of East Anglia & England \\
\hline
\end{tabular}

Figure 3 shows the collaborative work between authors. Daniel Scott has collaborated with more authors than any other (Hall, C.M., Rutty, M., and Gossling, S.) [19,37] who were interested in the implications of climate change on international tourism [37] as well as the thermal comfort and microclimates of coastal tourism facilities [19]. Another example of collaborative work can be found among Sutherland, W.J., Jones, A.P., and Coombes, E.G. [75]. Student, J., Steinmann, P., and Kramer, M.R. have also worked 
collaboratively [76]. In addition to these collaborations, Manuel Navarrete, D. and Buzindi, C. N. worked together [77].

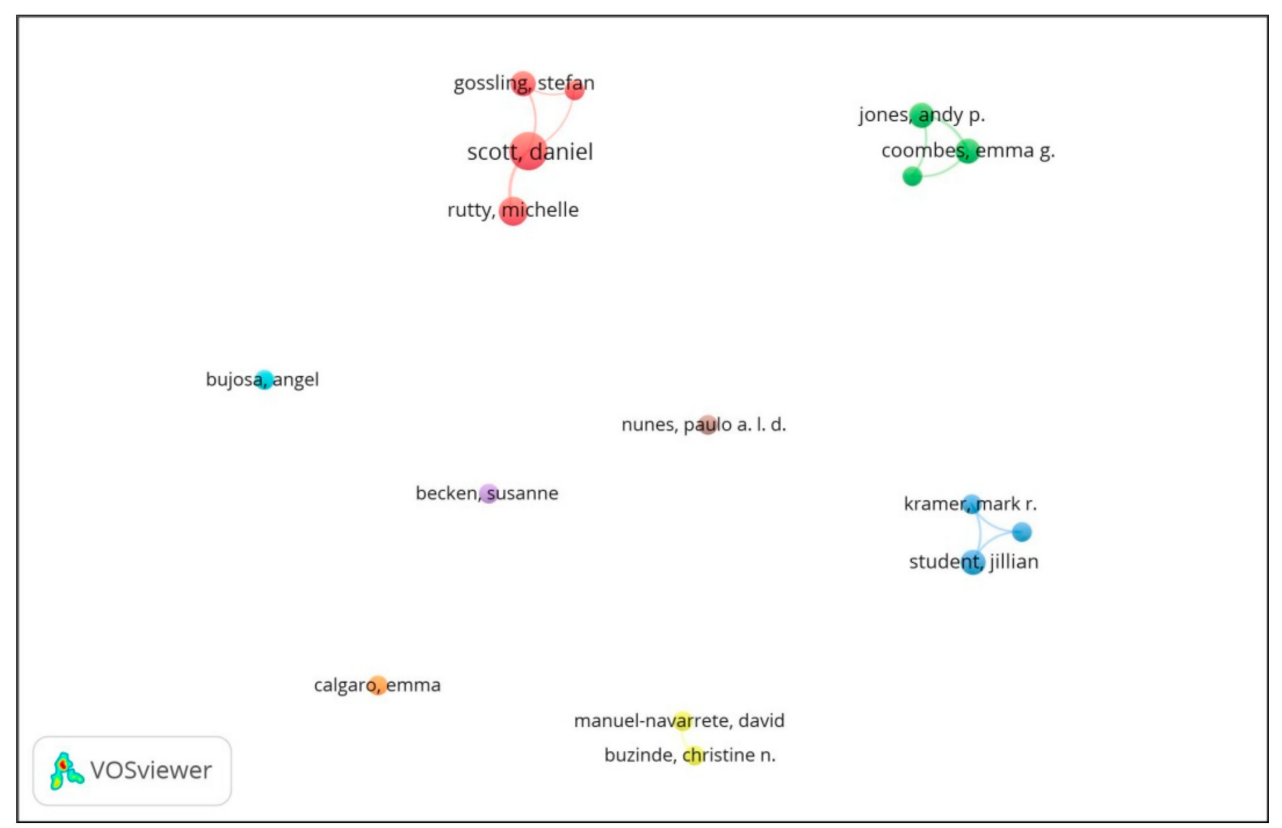

Figure 3. Co-authorship analysis of authors.

\subsection{Country and Institution Co-Author Analysis}

The number of publications held by each country in the WoS core collection and the number of citations each country indicated the most productive country in the particular research field [59]. The minimum number of documents and citations of the country for co-authorship was set to two. Thus, 22 countries met the minimum requirements out of 41 countries. Figure 4 shows the distribution of literature across countries. Four countries mainly influence the literature: The United States of America (16 documents, 402 citations), England (15 documents, 677 citations), Canada (11 documents, 490 citations), and Spain (9 documents, 352 citations). These countries represent the main significant clusters (USA: Blue, England: Red, Canada: Green, and Spain: purple). Netherlands (8 documents, 386 citations), Germany (7 documents, 449 citations), Australia (6 documents, 262 citations), France ( 6 documents, 91 citations), Italy ( 5 documents, 259 citations), and Portugal (5 documents, 49 citations) are among the top ten relevant countries. Despite having the highest number of publications, the United States collaborates only with England, Canada, Australia, and Indonesia. It is clear that England collaborates with more countries (11 countries: USA, Canada, Norway, Denmark, France, Germany, Spain, Netherlands, Italy, Kenya, and Greece) than any other countries do. It is important to note that among the top ten rated countries, England, Spain (with nine countries), and Canada (with seven countries) have great collaboration in climate change and coastal tourism research. Still, the opposite is true for the United States (one time).

The most influential institutions were also analysed using co-authorship analysis. The minimum number of documents and citations of an organization for co-authorship was set to two. Thus, 16 organizations met the minimum requirements, out of 177 organizations. Figure 5a presents the organizations involved in climate change coastal tourism research. In terms of the number of publications and citations, The University of Waterloo is the most productive and leading institute (with 7 publications and 427 citations), followed by the University of East Anglia (4 publications and 82 citations), the Pennsylvania State University (with 3 publications and 82 citations), and the University of Cambridge (with 3 publications and 57 citations). Figure $5 \mathrm{~b}$ reveals collaborations between universities. The University of Waterloo collaborates with the University of Oxford, Michigan State 
University, the University of Canterbury, and Linnaeus University. Other universities often do not engage with more than one.

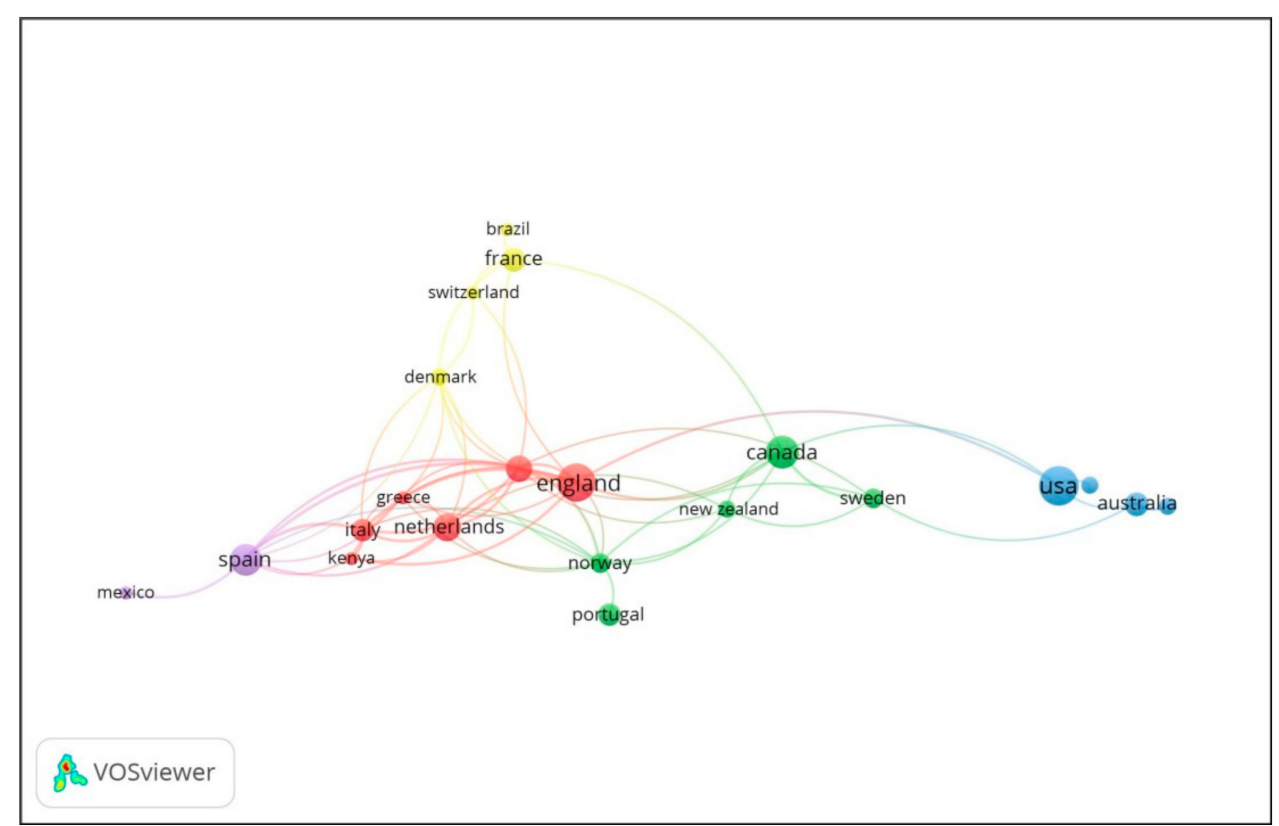

Figure 4. Co-authorship analysis network of countries.

The study consisted of 177 organizations from 41 countries (Figure 6). Less than two documents were published by $84.45 \%$ of the institutions, and only $15.54 \%$ of the institutes published more than five documents. Moreover, only $17.51 \%$ of the institutes received more than 100 citations, whereas $82.48 \%$ have less than 100 citations.

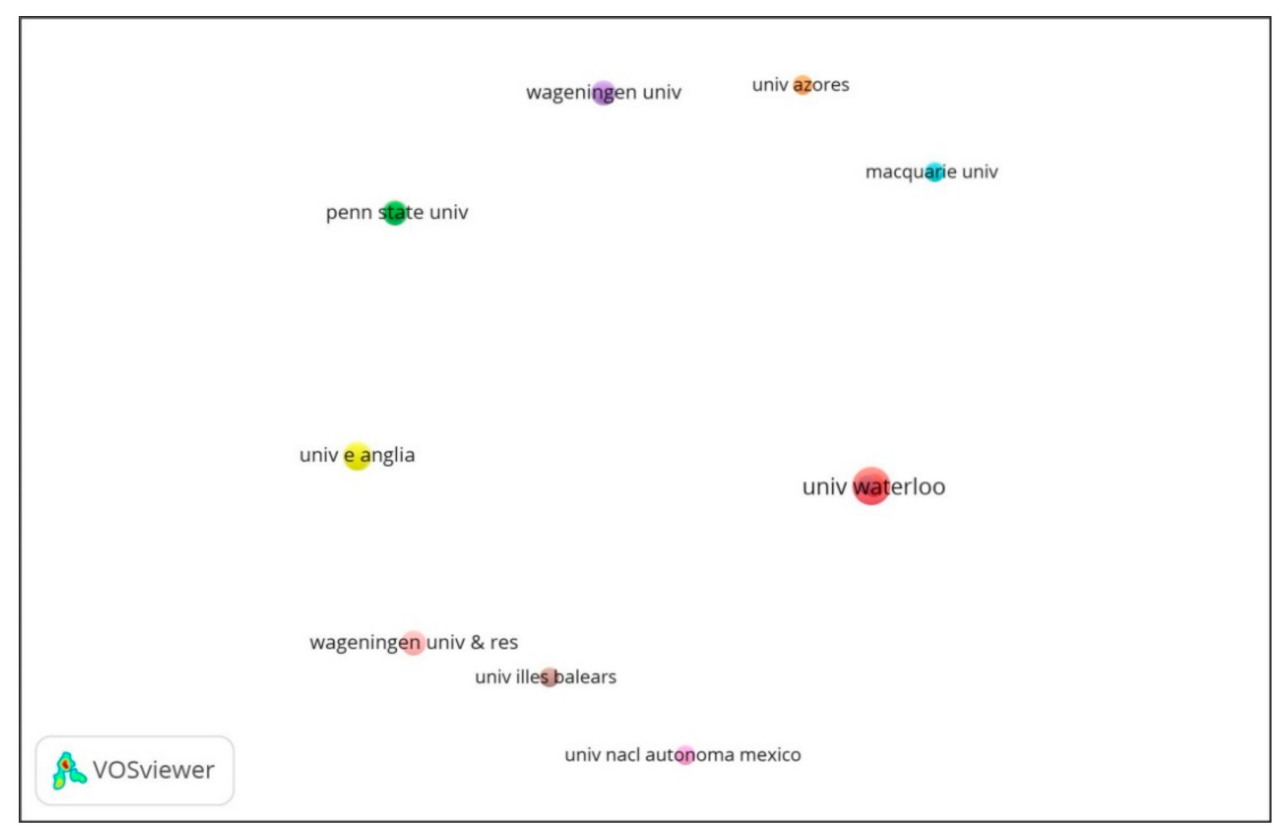

(a)

Figure 5. Cont. 


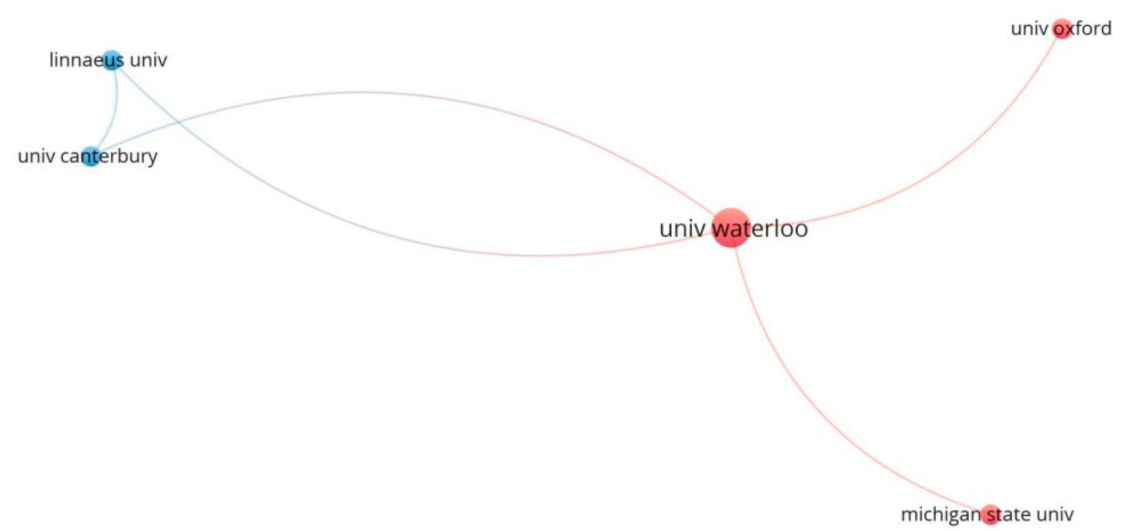

(b)

Figure 5. (a) Co-authorship analysis of institutions. (b) Co-authorship analysis of the University of Waterloo.

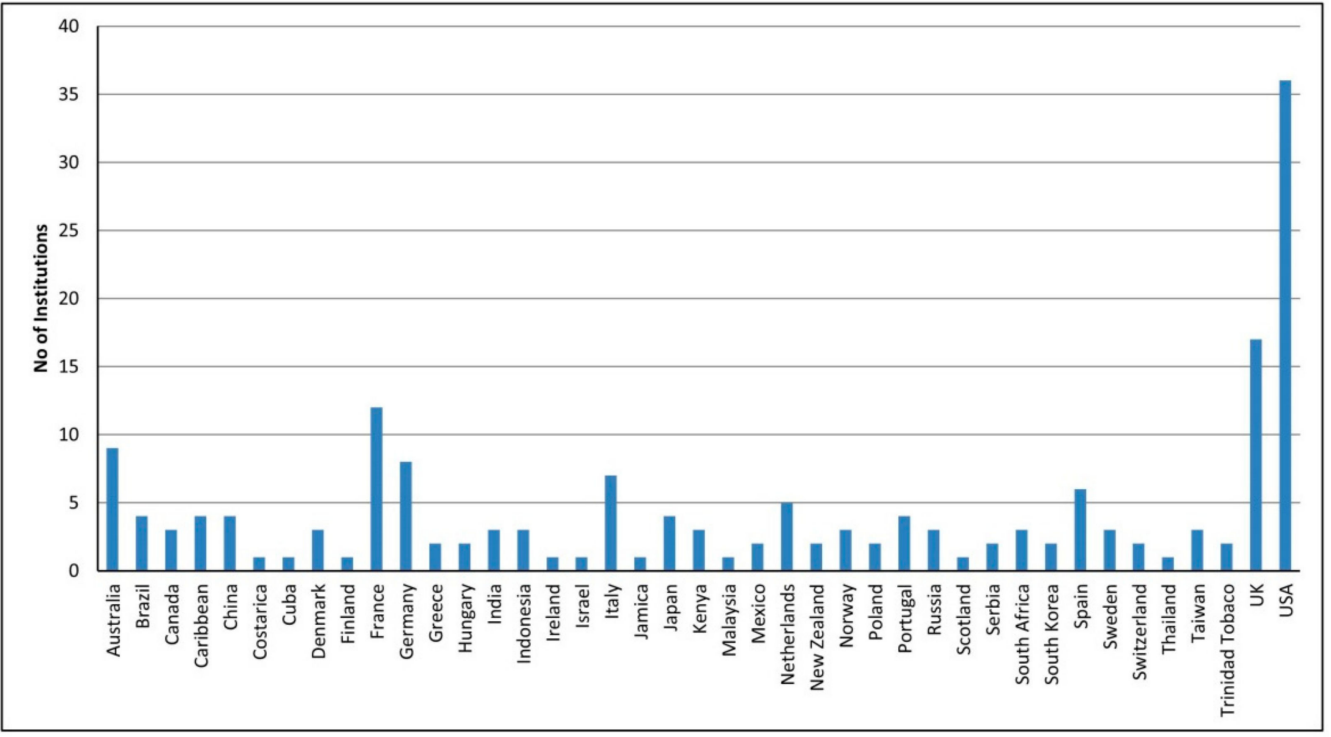

Figure 6. Countries and number of institutions involved.

\subsection{Keyword Co-Occurrence Analysis}

The emerging research domains and research themes of a particular field can be monitored by keyword co-occurrence analysis as keywords reveal the exact content of the article $[50,63,64]$. The author keyword co-occurrence analysis investigates the distribution of the most often occurring keywords. The aim is to highlight the most important research topics in climate change and coastal tourism by focusing solely on the author keywords below the abstract. The keyword co-occurrence technique counts the number of articles in which two keywords appear together. The author's keyword co-occurrence (which analyses the data of relationships among authors by using the coupling strength of the keywords in the authors' papers [78]) of this study is graphically shown in Figure 7a based on fractional counting. 


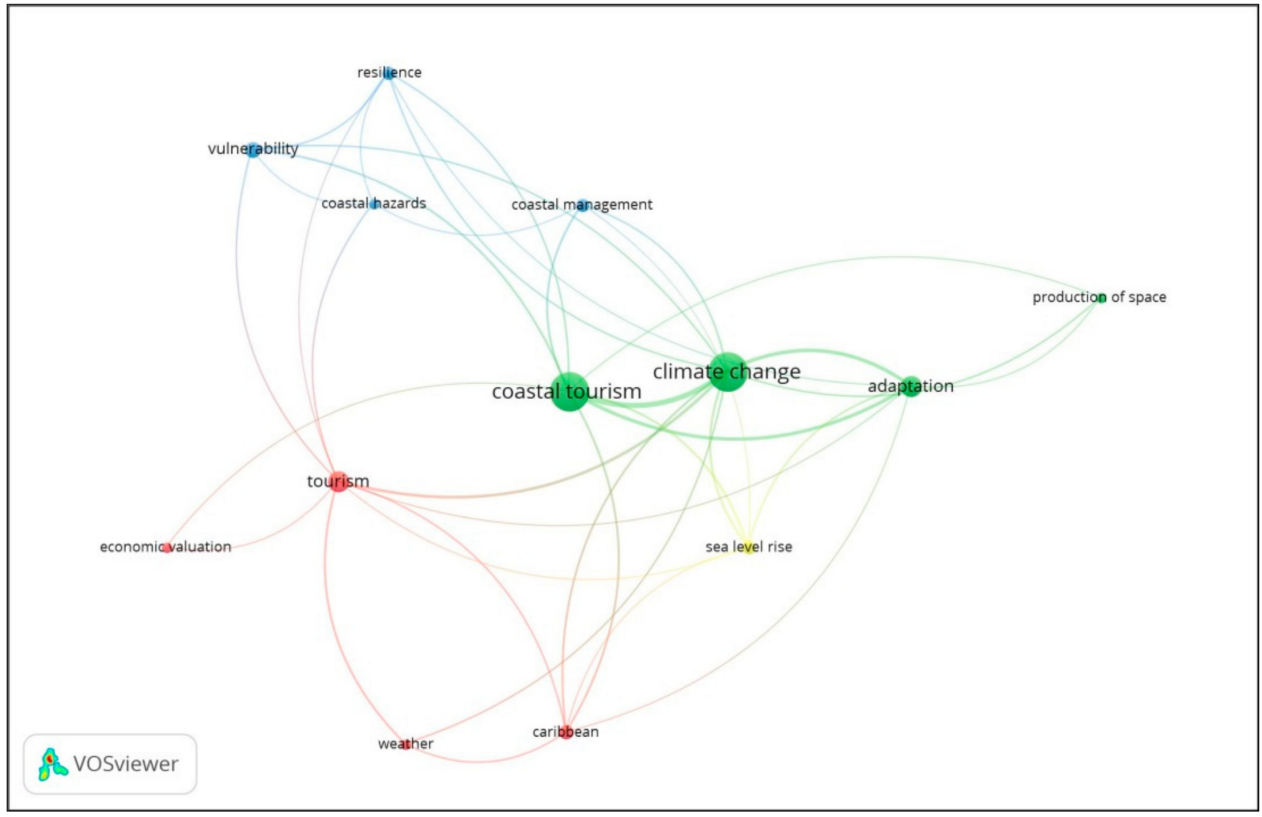

(a)

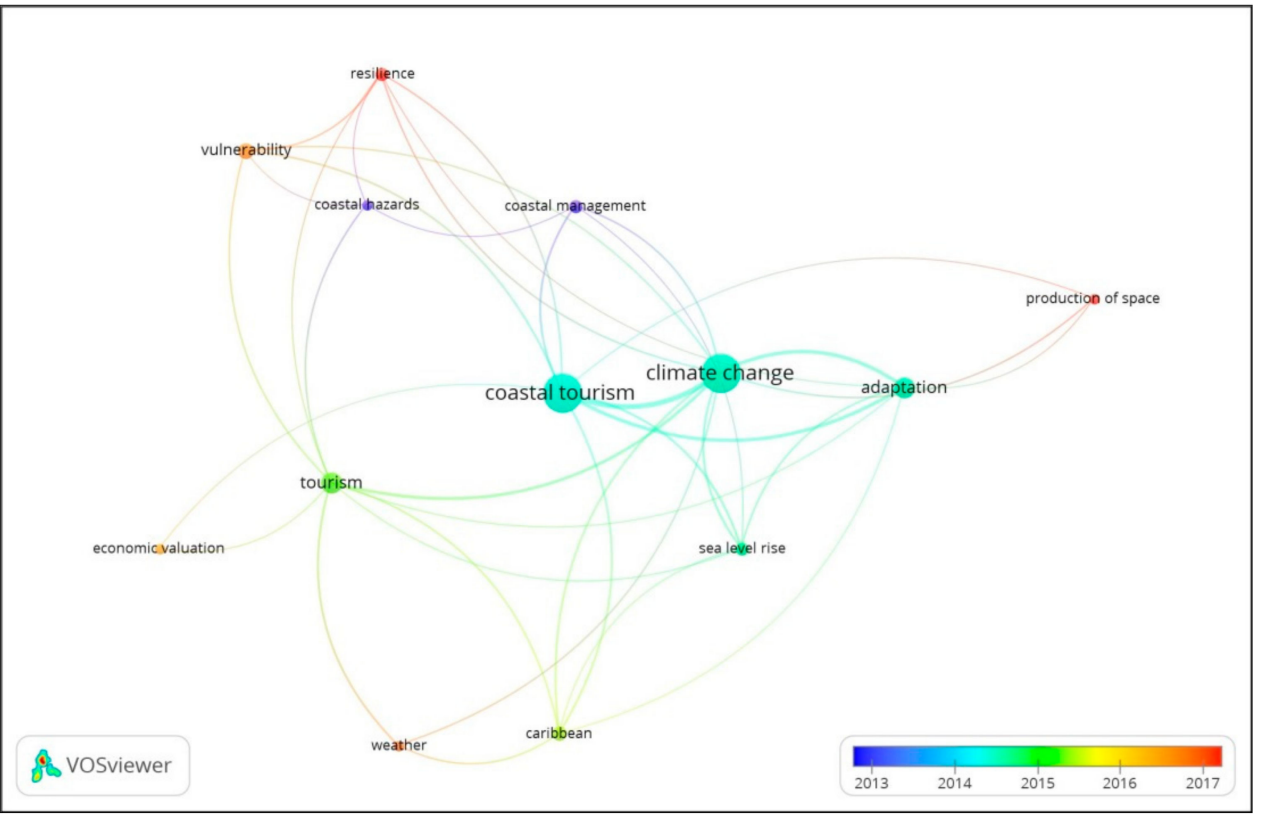

(b)

Figure 7. (a) Co-occurrence author keyword. (b) Co-occurrence author keyword by year.

The co-occurrence and linkage of keywords are visualized using the VOS viewer. Each circle represents a keyword in the visualization map. The size of the circle is the number of links with other keywords (number of times it was referred). The wider the circle, the more it connects to other keywords. The size of the node is directly proportional to the corresponding frequency of keyword co-occurrences. The keywords that are closer and similar in colour represent more similarities than the ones that are far with a different colour $[46,50,52]$. The width of the line between circles reflects the number of keywords co-occurring together $[46,50,52]$. The minimum number of keyword co-occurrences for the author's keyword co-occurrence was set to three. Thus, 13 keywords met the minimum requirements out of 255 occurrences of keywords. The top ten authors' keywords used in climate change and coastal tourism research between 1999 and 2020 included "climate change," "coastal tourism," "adaptation," "tourism," "vulnerability," "Caribbean," "coastal 
management," "resilience," "sea level rise," and "coastal hazards" (Table 5). There are four clusters with 13 nodes represented by different colours in the diagram (Figure 7a). The node with the keyword "climate change" (shown in green) has the most significant number of keywords co-occurring, followed by nodes with the keyword "coastal tourism," "adaptation," "tourism," "Caribbean," "sea level rise," "vulnerability," "resilience," "coastal management," and "coastal hazards". Table 5 displays the top 10 keywords, together with their co-occurrence frequency and total link strength.

Table 5. Top ten author keywords co-occurrence.

\begin{tabular}{ccc}
\hline Keyword & No of Co-Occurrences & Total Link Strength \\
\hline Climate change & 35 & 50 \\
Coastal tourism & 34 & 43 \\
Adaptation & 11 & 23 \\
Tourism & 11 & 19 \\
Vulnerability & 6 & 12 \\
Caribbean & 5 & 12 \\
Coastal management & 4 & 7 \\
Resilience & 4 & 9 \\
Sea level rise & 4 & 11 \\
Coastal hazards & 3 & 5 \\
\hline
\end{tabular}

In Figure 7a, the first cluster (in red) is represented by the term "tourism," which was cited 11 times in all analysed documents. The articles in this area contain research on the impact of weather parameters on a country's economic valuation. The second cluster, displayed in green, is led by the term "climate change," which was cited 35 times across all documents reviewed. This group's articles included research on the effects of climate change on coastal tourism and resilience to climate change. The third cluster (in blue) has "vulnerability" as the most cited term (six times in all documents surveyed). The articles of this group provided studies regarding the vulnerability of coastal hazards and coastal management for resilience from the hazards. The fourth cluster (in yellow) is represented by the term "sea level rise," cited four times in all surveyed documents. The articles of this group presented studies regarding the association of sea level rise with climate change, the impacts of sea level rise on tourism in general and coastal tourism in particular and adaptation mechanisms.

Figure $7 \mathrm{~b}$ depicts how some themes have been integrated into climate change and coastal tourism research. Some concepts have only lately been introduced into this field of research. Scientific investigations on climate change and coastal tourism were initially motivated to learn more about coastal hazards and coastal management. The study of the effects of climate change began later, including tourism in general and coastal tourism in particular. Once the impacts of climate change are identified, it is necessary to determine how risks might be reduced by using climate change adaptation strategies. Finally, it was demonstrated that the most recently used phrases are connected to how adaptation techniques to climate change can be included in resilience and productivity.

\subsection{Co-Citation Analysis}

Co-citation has been used to analyse authors, journals, and references within cocitation analysis. The frequency with which the later article includes sections of two earlier articles together is referred to as co-citation $[45,50,79]$. Co-citation analysis measures how many times in a third article, two articles are cited [50,64,66,67]. Co-citation analysis provides a platform for understanding the process of spatial growth. It can, therefore, be an effective tool for graphically depicting the intellectual structure of a subject. In addition, co-citation research offers a vital insight into the knowledge domain [45]. The co-citation analysis, with the "cited author" as the unit of analysis, is performed to identify the leading authors in the field. The minimum number of citations of an author was set to 10. Thus, 27 authors met the minimum requirement out of the 281 authors (Figure 8). 


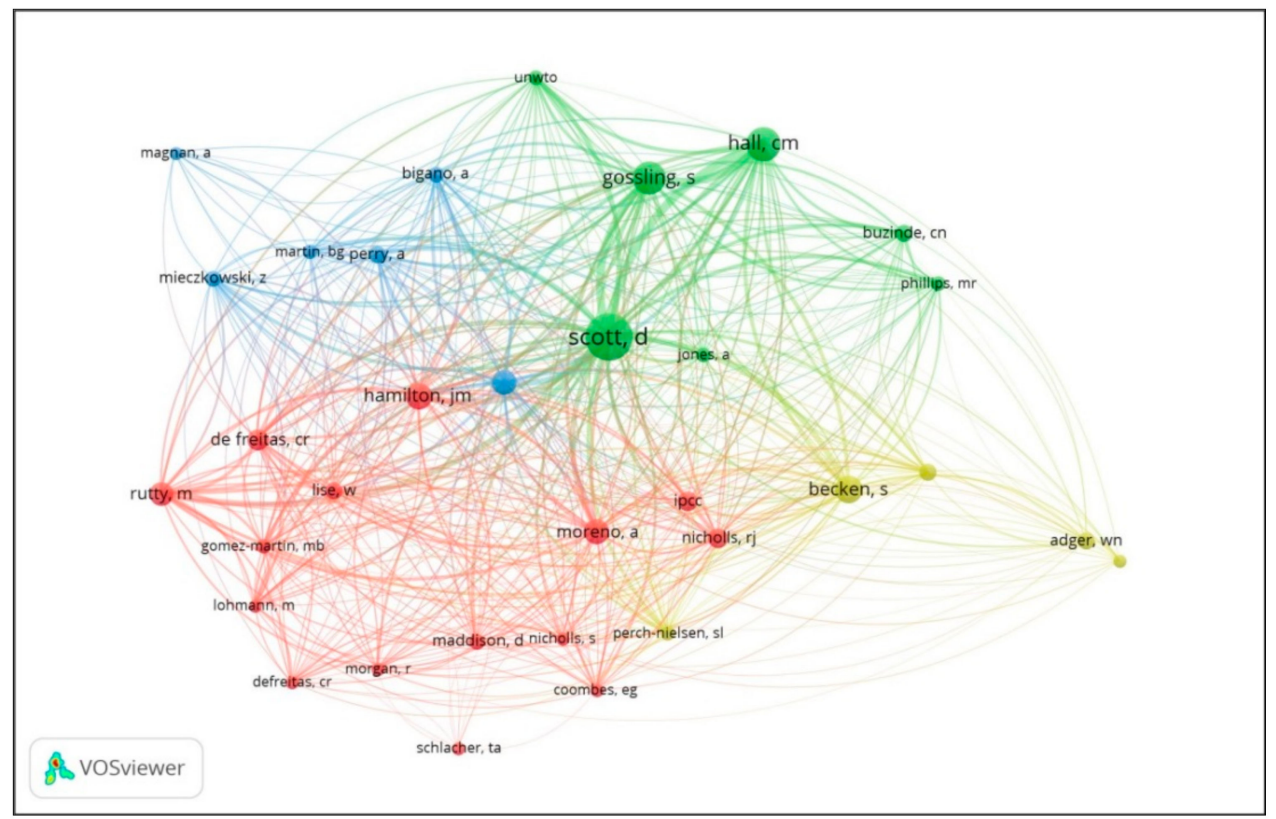

Figure 8. Co-citation analysis of "cited authors".

Initially, co-citation analysis focused on the main authors' network. Figure 8 depicts a co-citation analysis of "cited authors" with four clusters. The first cluster is exhibited in red, with 15 authors; the second cluster is shown in green, with seven authors; the third cluster is shown in blue, with six authors; and the last cluster is shown in yellow, with five authors only. However, when focusing on the citations, the primary cluster, which is the central cluster comprising of the most cited authors, is in green and represented by Scott, D. (127 citations), Hall, C. M. (65 citations), and Gossling, S. (62 citations) (Table 6). The work of the leading authors, which is displayed in the green cluster, focuses on climate change problems in tourism and vulnerability and adaptation to climate change. Scott, D., in particular, focuses on the impact of climate change on tourism. C. M. Hall focuses mostly on coastal tourism and its sensitivity to climate change. Gossling, S. focuses on tourist behaviour in relation to climate change, among other things.

Table 6. Co-citation analysis of "Cited Authors" (top ten).

\begin{tabular}{ccc}
\hline Author & Citations & Total Link Strength \\
\hline Scott, D. & 127 & 103.06 \\
Hall, C. M. & 65 & 51.3 \\
Gossling, S. & 62 & 55.28 \\
Becken, S. & 45 & 39.01 \\
Hamilton, J. M. & 42 & 39.18 \\
Moreno, A. & 37 & 34.79 \\
Amelung, B. & 36 & 34.12 \\
Rutty, M. & 28 & 24.68 \\
Nicholls, R. J. & 24 & 21.31 \\
De Freitas, C. R. & 23 & 22.25 \\
\hline
\end{tabular}

Based on the citations, the second most crucial cluster is shown in yellow. Although it focuses on climate change and coastal tourism, this is a multidisciplinary cluster. Becken, the cluster's leading author, is ranked number four, and his works highlight methodology for assessing climate change vulnerability on coastal tourism. The third major cluster, displayed in red, comprises authors ranked among the top ten. Hamilton, J. M. is the cluster's main author, and his studies mainly focus on the implications of climate change on international tourism. The fourth cluster is blue, and none of the authors are in the top ten authors in terms of citations. 
The second co-citation analysis concentrates on cited references. The minimum number of citations of "cited reference" was set to 10. Thus, 15 "cited references" met the minimum requirement out of the 4040 "cited references" (Figure 9). The cluster analysis of cited references showed that the article by Amelung [80] ranked first in the most cited paper and was cited 19 times in the 92 documents related to climate change and coastal tourism. This paper is the most cited article with 19 citations, and the 101 total link strength is in the cluster highlighted in red. Uyarra's second most cited article, with 17 citations [22], has a total link strength of 71. Scott's third most cited publication, with 17 citations [71], has a total link strength of 46 . The second and third papers are in the green-coloured cluster. Hall's fourth most cited publication, with 16 citations [14], has a total link strength of 69. Mieczkowski's fifth most cited publication, with 15 citations [81], has a total link strength of 91. These papers (ranked fourth and fifth) are likewise in the same cluster as the second and third papers. The most cited article by Amelung is about the future of Mediterranean tourism and the Tourism Climatic Index. In contrast, the second most cited article by Uyarra is about the implications of climate change for tourism. The third most cited article by Moreno relates to climate change and coastal and marine tourism.

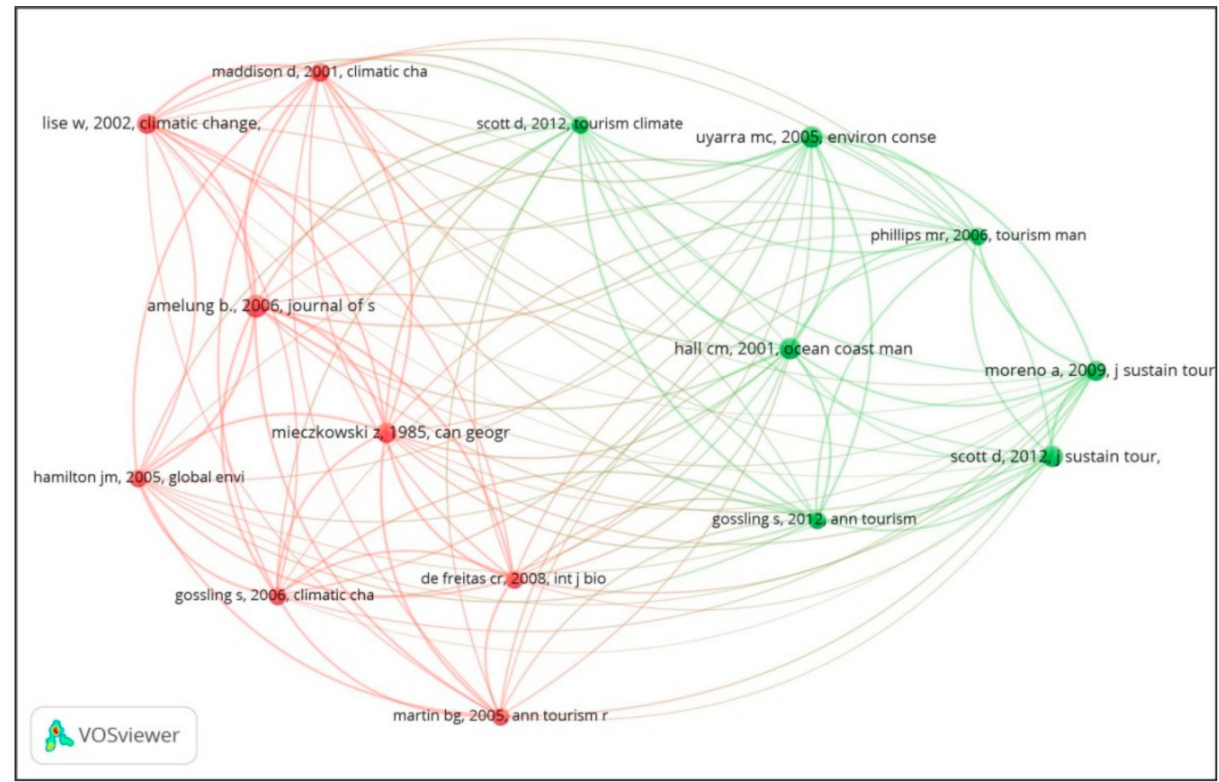

Figure 9. Co-citation analysis of cited references.

The minimum number of citations of "cited sources" was set to 30. Thus, 19 "cited sources" met the minimum requirement. The third co-citation analysis looked at the network of sources that were cited (journals). The results of the research indicated three clusters (Figure 10). The first cluster, shown in red, consists of seven journals: Ocean and Coastal Management, the fourth most-cited journal (105) with the highest link strength (1889), Global Environmental Change (93 citations, 1865 link strength), The Journal of Coastal Research (74 citations, 1178 link strength), Ecological Economics (44 citations, 856 link strength), Marine Policy (35 citations, 769 link strength), Environmental Conservation (33 citations, 647 link strength), and Biological Conservation (32 citations, 471 link strength). This cluster comprises journals that are more concerned with conservation.

The second cluster is shown in blue and consists of seven journals: Journal of Sustainable Tourism as the most cited journal (164) with the highest link strength (3215), Tourism Management (135 citations, 3026 link strength), Climatic Change (130 citations, 3034 link strength), Annals of Tourism Research (103 citations, 1994 link strength), International Journal of Biometeorology (74 citations, 1650 link strength), Climate Research (54 citations, 1450 link strength), and Current Issues in Tourism (40 citations, 1142 link strength). The majority of the journals in this cluster are concerned with current issues in tourism. The third cluster is represented by the blue colour, which includes five journals: Science (59 cita- 
tions, 1474 link strength), Nature Climate Change (41 citations, 1727 link strength), Global Change Biology (34 citations, 1653 link strength), Proceedings of the National Academy of Sciences (33 citations, 882 link strength), and PLOS One (30 citations, 1098 link strength). The journals in cluster three are mostly concerned with the environment. However, this cluster's journals all have lower citations and link strength than the previous two clusters.

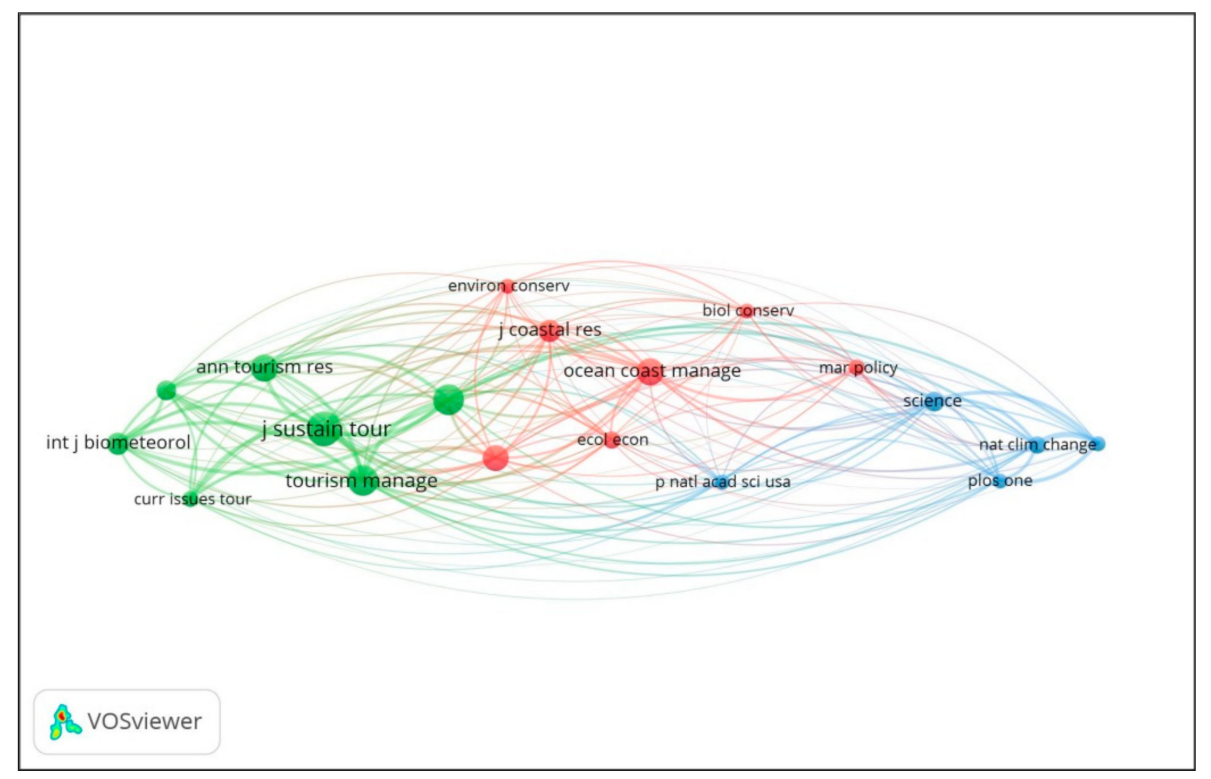

Figure 10. Co-citation analysis of cited sources.

\subsection{Bibliographic Coupling}

Bibliographic coupling is a method for analysing similarity that provides a different viewpoint on the subject of an author's work and is utilised to supplement co-citation analysis [48]. It is also a science mapping technique that assumes two articles that share common references are similar in content [48,82]. When two articles cite the third article, this is referred to as bibliographic coupling $[64,66,67]$. The recent and niche publications can be made visible as thematic clusters are established in bibliographic coupling, based on the cited publications [48]. The bibliographic coupling analysis, with "author" as the unit of analysis, is carried out to provide a graphic analysis of the bibliographic coupling of authors. The minimal number of publications and citations for an author was set to two and five, respectively. As a result, 14 authors out of 281 met the minimum criterion. Figure 11 depicts the bibliographic coupling of the authors. Scott, Daniel topped the list in terms of link strength and number of documents, with seven documents and 1892 link strength, followed by Rutty (four documents and 1138 link strength), Gossling (three documents and 822 link strength), Coombes (three documents and 638 link strength), and Jillian (three documents and 638 link strength) (three documents and 78 link strength). Figure 11 describes four clusters. The first cluster is depicted in red, and it is led by Student (three documents and 78 link strength) and contains four more authors (Becken, Buzinde, Calgaro, and Manuel-Navarrete). Green represents the second cluster, which is made up of four authors (Gossling, Hall, Bujosa, and Nunes) and is chaired by Gossling. The third cluster is indicated in blue, and it is led by Coombes and consists of two more authors (Jones and Sutherland). The fourth cluster is yellow, with two authors (Rutty and Scott), led by Scott. The work of the majority of the authors has already been discussed in the preceding sections. On the other hand, this approach provides a few scholars with a novel viewpoint for analysing climate change and coastal tourism. Buzinde from Pennsylvania State University, in particular, did research on representation and climate change. Finally, Sutherland's (2008) research focuses on the spatial and temporal modelling of beach use to optimize coastal land for tourism [83]. 


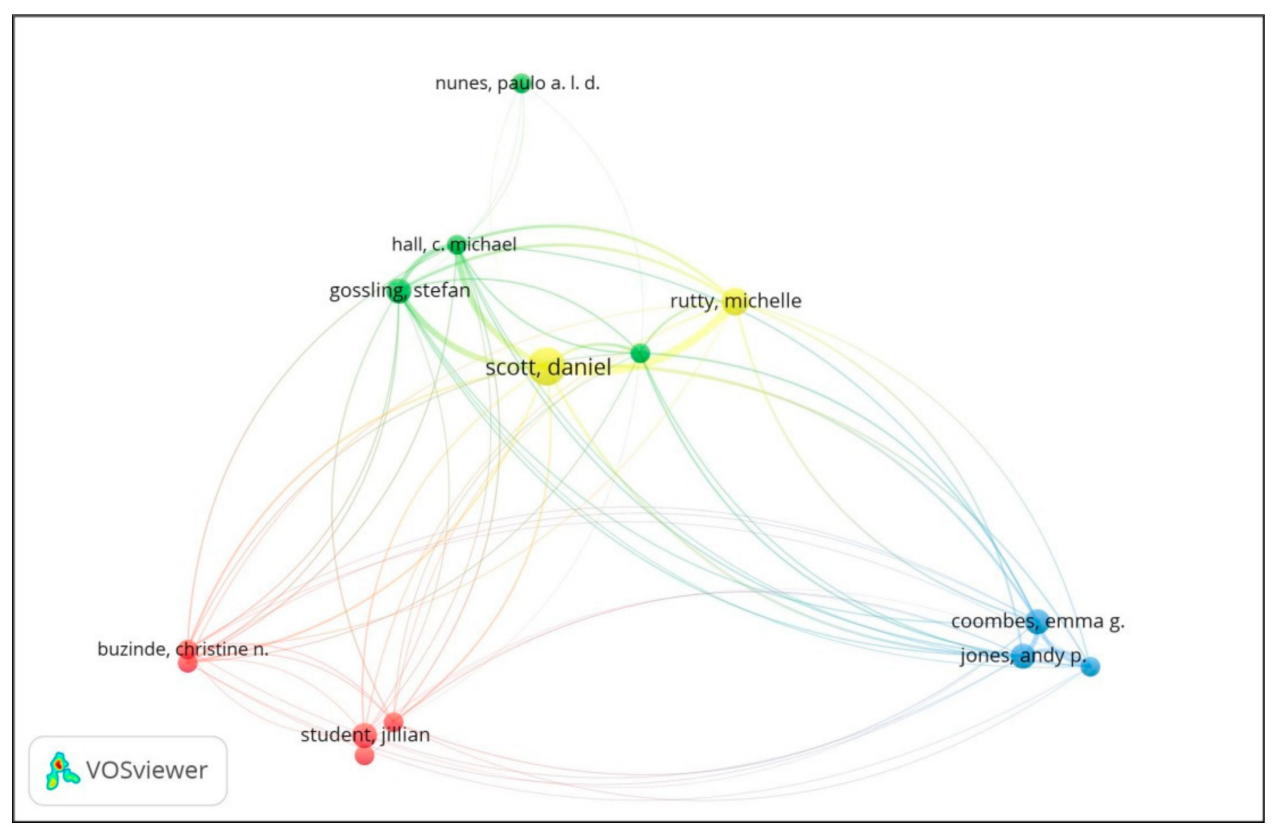

Figure 11. Bibliographic coupling of authors.

\section{Discussion}

This paper consists of a comprehensive bibliometric analysis on research related to climate change and coastal tourism by analysing 92 documents listed in the WoS core collection database. It provides a clear overview of the number of publications, the most cited articles, and the most influential authors, institutions, and countries in the field from 1999 to 2020, using a wide range of bibliometric techniques enabled by the WoS.

This study indicates various publications, organizations, and countries interested in climate change and coastal tourism research. According to co-authorship analysis, the United States, England, Canada, and Spain are the leading countries in the field. The analysis also shows that the most influential institutions are the University of Waterloo, the University of East Anglia, and Pennsylvania State University. The analysis further reveals a lack of collaboration between universities, except for the University of Waterloo. Additionally, while being a relatively new field of study, results show that research on climate change and coastal tourism has emerged concurrently across different academic disciplines and is advancing. The results show that despite fluctuations from one year to the next over the period from 1999 to 2020, the number of publications on climate change and coastal tourism field has grown between 2007 and 2020. Despite an expanding tendency, literature on climate change and coastal tourism is still limited. This paper is a pioneer in analysing this aspect.

Keyword co-occurrence analysis was performed to understand the emerging domains in climate change and coastal tourism. The top five most frequent "author keywords" are "climate change," "coastal tourism," "adaptation," "tourism," "Caribbean," and "sea level rise". The analysis of the keywords used by authors in the past 20 years of scientific literature on climate change and coastal tourism shows that research in this subject was first focused on evaluating impacts and exposure to hazards. This has evolved, and the emphasis has switched to adaptation and resilience measures to mitigate the consequences of climate change on coastal tourism. This is consistent with the observation that, with a few exceptions, the primary components in climate change and coastal tourism literature are constant and emphasize the emerging area. The findings also show that vulnerability, resilience, economic valuation, and production of space have yet to fully integrate into climate change and coastal tourism.

The visual analysis consists of keyword co-occurrence, co-citation, and bibliographic coupling. The result of the graphical analysis was similar to the data collected from the WoS database. Co-citation analysis of cited references shows that the article by Amelung, 
ranked first in most cited paper, was cited 19 times in the 92 documents related to climate change and coastal tourism and was displayed in the first cluster. The second and third most cited documents are included in the second cluster. The co-citation analysis of cited references indicates that the clusters are relatively dispersed. The co-citation analysis of cited sources is categorized into three clusters. The first cluster, led by Ocean and Coastal Management, consists of seven journals primarily focused on conservation. The second cluster consists of seven journals, led by the Journal of Sustainable Tourism. The majority of the journals in this cluster deal with current tourist challenges. The third cluster, led by science, consists of five journals primarily focused on the environment. Co-citation analysis of cited authors is presented with four clusters. The central cluster, ley by Scott D., Hall C.M., and Goossling S., concentrates on tourism and climate change from different perspectives. The relationship of the central cluster with others is also illustrated. Climate change and vulnerability assessment methods (Becken, Moreno), climate change implications (Hamilton), and tourism climatic index (Amelung) are the major topics of the surrounding clusters.

The bibliographic coupling of authors illustrates the existence of four clusters, two of which include more than five authors each. Scott Daniel and Rutty Michelle lead the main cluster with 1892, and 1138 link strength, respectively. This analysis provided a different perspective for analysing climate change and coastal tourism: a biophysical perspective (Buzinde, Manuel-Navarrete, Kerstetter, Redclift) and a behavioural perspective (Coombes, Jones), for example.

\section{Conclusions}

This paper elaborates a strong overview of the most influential studies on climate change and coastal tourism, despite several constraints. The article also provides a basis for possible bibliometric studies in this field. The theoretical importance of this study is that this bibliometric analysis can provide some answers to the research questions to be examined in a paper on climate change and coastal tourism. In particular, researchers will acquire a better broad perspective of literature on climate change and coastal tourism, including growth, new trends, and prominent literature and countries. Apart from this, this research indicates that the theme of climate change and coastal tourism extends from a traditional (e.g., impacts, vulnerability, and hazards) to a modern perspective (e.g., production of space and economic evaluation). This study indicates that climate change and coastal tourism will eventually expand into some of the most popular fields in general academia. Although the studies on this topic are still limited, it has the potential to integrate into other significant scientific areas (management, information technology, and programming). Some of the relevant keywords (space production and economic evaluation) were relatively low in importance, indicating that some areas of climate change and coastal tourism require additional research. Furthermore, the results show that most studies on climate change and coastal tourism are empirical. Therefore, articles on developing indicators to measure the effects of climate change on coastal tourism are in great demand.

It is observed that more attention should be placed on developing countries, as the bulk of research in this field has been focused exclusively on tourist destinations in developed countries. Although a considerable number of publications in this field can be found in America and Europe, very few papers in this field have been published in South Asia in general and Sri Lanka in particular. Despite growing recognition that climate change disrupts tourism and other coastal economic activities in developing countries, this study found that only a small number of South Asian countries (5 out of 41 countries, e.g., China, India, Indonesia, Taiwan, and Thailand), institutions (13 out of 177 institutions) and authors (33 out of the 281 Authors) have been involved in climate change and coastal tourism research, which may explain why there have been fewer publications from South Asia. In addition, difficulties (e.g., publication cost) in publishing articles from South Asia in reputable databases (e.g., Web of Science and Scopus) may also be attributed to fewer publications. The results of this analysis are dynamic. It is also expected to change over 
the years based on the number of citations obtained in recent publications. Therefore, a broader thematic and content analysis is recommended to weed out irrelevant literature and capture a larger core of climate change and coastal tourism literature.

There are some methodological constraints and potential biases in this study. The data was extracted from the WoS core collection using selected keywords. Therefore, language bias may occur in the study since those keywords were in English. Local and scientific knowledge from other scientific sources could also be restricted. The number of citations and publications can slightly differ as the data is obtained at a given time. Also, several articles exclusively dedicated to climate change and coastal tourism might not be published in the Web of Science core collection. Further studies in the following areas can be conducted to expand the depth and scope of this study: more studies relating to climate change and coastal tourism, regardless of written language, can be analysed and compared to the findings of this study; various mapping techniques can be used to generate a comprehensive domain mapping of climate change and coastal tourism; and bibliometric surveys of scientific literature on climate change and coastal tourism can be restricted to the most prominent tourism journals to consider the field from a specific viewpoint. Besides that, methods and techniques used in this study can be repeated to characterize other knowledge domains and serve as a reference for future research in this field. It is pertinent to note that various indicators and techniques should be employed to investigate and elaborate on climate change and coastal tourism as it is an interdisciplinary, dynamic, and evolving research area.

Author Contributions: Conceptualization, V.P., S.N.C. and H.C.G.; methodology, V.P., S.N.C. and H.C.G.; software, V.P.; formal analysis, V.P.; investigation, V.P.; resources, V.P.; data curation, V.P.; writing-original draft preparation, V.P.; writing-review and editing, V.P., S.N.C. and H.C.G.; visualization, V.P.; supervision, S.N.C. and H.C.G.; project administration, V.P. All authors have read and agreed to the published version of the manuscript.

Funding: This research received no external funding.

Institutional Review Board Statement: Not applicable.

Informed Consent Statement: Not applicable.

Data Availability Statement: The data that support the findings of this study are openly available in Web of Science Core Collection at https: / / www-webofscience-com.ezproxy.um.edu.my / wos / woscc/ summary/7038395a-42de-4ad0-8012-2e1088d2dc73-00aabbb2/relevance/1 accessed on 4 December 2020.

Acknowledgments: The author (Pathmanandakumar, V) wishes to express his sincere thanks to AHEAD Project for providing financial support for the PhD programme as well as to the Eastern University-Sri Lanka for their constructive support. We thank the reviewers for their insightful comments, which helped to improve the article.

Conflicts of Interest: The authors declare no conflict of interest. Also, the funders had no role in the design of the study, in the collection, analyses, or interpretation of data, in the writing of the manuscript, or in the decision to publish the results.

\section{References}

1. Wall, G.; Harrison, R.; Kinnaird, V.; McBoyle, G.; Quinlan, C. The implications of climatic change for camping in Ontario. Recreat. Res. Rev. 1986, 13, 50-60.

2. Amelung, B.; Moreno, A.; Scott, D. The Place of Tourism in the IPCC Fourth Assessment Report: A Review. Tour. Rev. Int. 2008, 12, 5-12. [CrossRef]

3. Scott, D.; Becken, S. Adapting to climate change and climate policy: Progress, Problems and potentials. J. Sustain. Tour. 2010, 18, 283-295. [CrossRef]

4. Ramasamy, R.; Swamy, A. Global Warming, Climate Change and Tourism: A Review of Literature. Cult. Rev. Cult. Tur. 2012, 6, 72-98.

5. Chen, L.; Thapa, B.; Yan, W. The relationship between tourism, carbon dioxide emissions, and economic growth in the Yangtze River Delta, China. Sustainability 2018, 10, 2118. [CrossRef] 
6. UNWTO; ITF. Transport-Related $\mathrm{CO}_{2}$ Emissions of the Tourism Sector; World Tourism Organization (UNWTO): Madrid, Spain, 2019; ISBN 9789284416660.

7. Lenzen, M.; Sun, Y.Y.; Faturay, F.; Ting, Y.P.; Geschke, A.; Malik, A. The carbon footprint of global tourism. Nat. Clim. Chang. 2018, 8, 522-528. [CrossRef]

8. UNWTO; UNEP. Climate Change and Tourism-Responding to Global Challenges; World Tourism Organization and United Nations Environment Programme Climate: Madrid, Spain, 2008; ISBN 9789284412341.

9. Grimm, I.J.; Alcântara, L.C.S.; Sampaio, C.A.C. Tourism under climate change scenarios: Impacts, possibilities, and challenges. Braz. J. Tour. 2018, 12, 1-22. [CrossRef]

10. Scott, D. Sustainable tourism and the grand challenge of climate change. Sustainability 2021, 13, 1966. [CrossRef]

11. Ansari, J.A.; Umar, R. Evaluation of hydrogeochemical characteristics and groundwater quality in the quaternary aquifers of Unnao District, Uttar Pradesh, India. HydroResearch 2019, 1, 36-47. [CrossRef]

12. Karia, J.P.; Porwal, M.C.; Roy, P.S.; Sandhya, G. Forest change detection in Kalarani round, Vadodara, Gujarat-A Remote Sensing and GIS approach. J. Indian Soc. Remote Sens. 2001, 29, 129. [CrossRef]

13. Damm, A.; Köberl, J.; Stegmaier, P.; Jiménez Alonso, E.; Harjanne, A. The market for climate services in the tourism sector-An analysis of Austrian stakeholders' perceptions. Clim. Serv. 2020, 17, 100094. [CrossRef]

14. Hall, C.M. Trends in ocean and coastal tourism: The end of the last frontier? Ocean Coast. Manag. 2001, 44, 601-618. [CrossRef]

15. Umarella, M.R.; Baiquni, M.; Murti, S.H.; Marfai, M.A. Sustainability challenges in developing marine-based adventure tourism in Ambon. IOP Conf. Ser. Earth Environ. Sci. 2021, 744. [CrossRef]

16. Nitivattananon, V.; Srinonil, S. Enhancing coastal areas governance for sustainable tourism in the context of urbanization and climate change in eastern Thailand. Adv. Clim. Chang. Res. 2019, 10, 47-58. [CrossRef]

17. Rutty, M.; Scott, D. Comparison of climate preferences for domestic and international beach holidays: A case study of Canadian travelers. Atmosphere 2016, 7, 30. [CrossRef]

18. Rutty, M.; Scott, D. Bioclimatic comfort and the thermal perceptions and preferences of beach tourists. Int. J. Biometeorol. 2015, 59, 37-45. [CrossRef]

19. Rutty, M.; Scott, D. Differential climate preferences of international beach tourists. Clim. Res. 2013, 57, 259-269. [CrossRef]

20. Rutty, M.; Scott, D. Thermal range of coastal tourism resort microclimates. Tour. Geogr. 2014, 16, 346-363. [CrossRef]

21. Arabadzhyan, A.; Figini, P.; García, C.; González, M.M.; Lam-González, Y.E.; León, C.J. Climate change, coastal tourism, and impact chains-a literature review. Curr. Issues Tour. 2021, 24, 2233-2268. [CrossRef]

22. Uyarra, M.C.; Côté, I.M.; Gill, J.A.; Tinch, R.R.T.; Viner, D.; Watkinson, A.R. Island-specific preferences of tourists for environmental features: Implications of climate change for tourism-dependent states. Environ. Conserv. 2005, 32, 11-19. [CrossRef]

23. Lóránt, D.; Zoltán, B.; Csaba, P.; Tuohino, A. Lake Tourism and Global Climate Change: An integrative approach based on Finnish and Hungarian case-studies. Carpathian J. Earth Environ. Sci. 2012, 7, 121-136.

24. Wong, P.P.; Losada, I.J.; Gattuso, J.P.; Hinkel, J.; Khattabi, A.; McInnes, K.L.; Saito, Y.; Sallenger, A.; Nicholls, R.J.; Santos, F.; et al. Coastal Systems and Low-Lying Areas; Barros, V.R., Field, C.B., Dokken, D.J., Mastrandrea, M.D., Mach, K.J., Bilir, T.E., Chatterjee, M., Ebi, K.L., Estrada, Y.O., Genova, R.C., et al., Eds.; Cambridge University Press: New York, NY, USA, 2014; ISBN 9781107415379.

25. Scott, D.; Hall, M.; Gössling, S. Tourism and Climate Change: Impacts, Adaptation and Mitigation, 1st ed.; Routledge: London, UK, 2012; ISBN 978-0-203-12749-0.

26. Weatherdon, L.V.; Magnan, A.K.; Rogers, A.D.; Sumaila, U.R.; Cheung, W.W.L. Observed and projected impacts of climate change on marine fisheries, aquaculture, coastal tourism, and human health: An update. Front. Mar. Sci. 2016, 3. [CrossRef]

27. Kopp, R.E.; DeConto, R.M.; Bader, D.A.; Hay, C.C.; Horton, R.M.; Kulp, S.; Oppenheimer, M.; Pollard, D.; Strauss, B.H. Evolving Understanding of Antarctic Ice-Sheet Physics and Ambiguity in Probabilistic Sea-Level Projections. Earth's Future 2017, 5, 1217-1233. [CrossRef]

28. Le Bars, D.; Drijfhout, S.; De Vries, H. A high-end sea level rise probabilistic projection including rapid Antarctic ice sheet mass loss. Environ. Res. Lett. 2017, 12. [CrossRef]

29. Brown, P.T.; Caldeira, K. Greater future global warming inferred from Earth's recent energy budget. Nature 2017, 552, 45-50. [CrossRef] [PubMed]

30. Jevrejeva, S.; Jackson, L.P.; Grinsted, A.; Lincke, D.; Marzeion, B. Flood damage costs under the sea level rise with warming of $1.5^{\circ} \mathrm{C}$ and $2{ }^{\circ} \mathrm{C}$. Environ. Res. Lett. 2018, 13. [CrossRef]

31. Mendoza-gonz, G.; Mart, M.L.; Id, R.G.; Octavio, P.; Howard, A. Towards a Sustainable Sun, Sea, and Sand Tourism: The Value of Ocean View and Proximity to the Coast. Sustainability 2018, 10, 1012. [CrossRef]

32. Hamilton, J.M.; Maddison, D.J.; Tol, R.S.J. Effects of climate change on international tourism. Clim. Res. 2005, 29, 245-254. [CrossRef]

33. Gómez Martín, M.B. Weather, climate and tourism: A geographical perspective. Ann. Tour. Res. 2005, 32, 571-591. [CrossRef]

34. Amelung, B.; Nicholls, S.; Viner, D. Implications of global climate change for tourism flows and seasonality. J. Travel Res. 2007, 45, 285-296. [CrossRef]

35. Moreno, A.; Becken, S. A climate change vulnerability assessment methodology for coastal tourism. J. Sustain. Tour. 2009, 17, 473-488. [CrossRef]

36. Buzinde, C.N.; Manuel-Navarrete, D.; Yoo, E.E.; Morais, D. Tourists' perceptions in a climate of change: Eroding Destinations. Ann. Tour. Res. 2010, 37, 333-354. [CrossRef] 
37. Scott, D.; Hall, M.; Gössling, S. International tourism and climate change. Wiley Interdiscip. Rev. Clim. Chang. $2012,3,213-232$. [CrossRef]

38. Gössling, S.; Scott, D.; Hall, C.M.; Ceron, J.P.; Dubois, G. Consumer behaviour and demand response of tourists to climate change. Ann. Tour. Res. 2012, 39, 36-58. [CrossRef]

39. Burns, P.; Bibbings, L. Climate change and tourism. In The Routledge Handbook of Tourism and the Environment; Holden, A., Fennell, D., Eds.; Routledge: London, UK; New York, NY, USA,, 2013; pp. 406-420, ISBN 9780203121108.

40. Ahmed, M.; Suphachalasai, S. Assessing the Costs of Climate Change and Adaptation in South Asia; Asian Development Bank: Mandaluyong, Philippines, 2014; ISBN 9789292545109.

41. Scott, D. Climate Change Implications for Tourism. In The Wiley Blackwell Companion to Tourism; Lew, A.A., Hall, C.M., Williams, A.M., Eds.; John Wiley \& Sons, Inc.: West Sussex, UK, 2014; pp. 1-668, ISBN 0631235647.

42. Gössling, S.; Hall, C.M.; Scott, D. Coastal and Ocean Tourism. In Handbook on Marine Environment Protection; Salomon, M., Markus, T., Eds.; Springer International Publishing: Cham, Switzerland, 2018; Volume 1-2, pp. 773-790, ISBN 9783319601540.

43. Buultjens, J.; Ratnayake, I.; Gnanapala, W.K.A. Case Study Sri Lanka: Climate Change Challenges for the Sri Lankan Tourism Industry. In Global Climate Change and Coastal Tourism: Recognizing Problems, Managing Solutions and Future Expectations; Jones, A., Phillips, M., Eds.; CAB International: Oxfordshire, UK; Boston, MA, USA, 2018; Volume 18, pp. 200-211, ISBN 9781780648453.

44. Scott, D.; Hall, M.; Gössling, S. Global tourism vulnerability to climate change. Ann. Tour. Res. 2019, 77, 49-61. [CrossRef]

45. Fang, Y.; Yin, J.; Wu, B. Climate change and tourism: A scientometric analysis using CiteSpace. J. Sustain. Tour. 2018, 26, 108-126. [CrossRef]

46. Lima, C.O.; Bonetti, J. Bibliometric analysis of the scientific production on coastal communities' social vulnerability to climate change and to the impact of extreme events. Nat. Hazards 2020, 102, 1589-1610. [CrossRef]

47. José, M.; Aparecida, M.; Barreiros, E.; Souza, D. Geospatiality of climate change perceptions on coastal regions: A systematic bibliometric analysis. Geogr. Sustain. 2020, 1-11. [CrossRef]

48. Donthu, N.; Kumar, S.; Mukherjee, D.; Pandey, N.; Marc, W. How to conduct a bibliometric analysis: An overview and guidelines. J. Bus. Res. 2021, 133, 285-296. [CrossRef]

49. Mulet-Forteza, C.; Genovart-Balaguer, J.; Mauleon-Mendez, E.; Merigó, J.M. A bibliometric research in the tourism, leisure and hospitality fields. J. Bus. Res. 2019, 101, 819-827. [CrossRef]

50. Mulet-Forteza, C.; Martorell-Cunill, O.; Merigó, J.M.; Genovart-Balaguer, J.; Mauleon-Mendez, E. Twenty five years of the Journal of Travel \& Tourism Marketing: A bibliometric ranking. J. Travel Tour. Mark. 2018, 35, 1201-1221. [CrossRef]

51. Garrigos-Simon, F.J.; Narangajavana-Kaosiri, Y.; Lengua-Lengua, I. Tourism and sustainability: A bibliometric and visualization analysis. Sustainability 2018, 10, 1976. [CrossRef]

52. Rana, I.A. Disaster and climate change resilience: A bibliometric analysis. Int. J. Disaster Risk Reduct. 2020, 50, 101839. [CrossRef]

53. Moher, D.; Liberati, A.; Tetzlaff, J.; Altman, D.G.; Group, P. Reporting Preferred reporting items for systematic reviews and meta-analyses: The PRISMA statement. BMJ 2009, 339, 332-336. [CrossRef]

54. De Oliveira, O.J.; Francisco, F.; Juliani, F.; César, L.; Motta, F. Bibliometric Method for Mapping the State-of-the-Art and Identifying Research Gaps and Trends in Literature: An Essential Instrument to Support the Development of Scientific Projects. J. Bus. Res. 2021, 133, 285-296.

55. Liao, H.; Tang, M.; Luo, L.; Li, C.; Chiclana, F.; Zeng, X. A Bibliometric Analysis and Visualization of Medical Big Data Research. Sustainability 2018, 10, 166. [CrossRef]

56. Garfield, E.; Sher, I.H.; Torpie, R.J. The Use of Citation Data in Writing the History of Science; Institute for Scientific Information Inc: Philadelphia, PA, USA, 1964.

57. Aghajani, M.A. Applying GIS to Identify the Spatial and Temporal Patterns of Road Applying GIS to Identify the Spatial and Temporal Patterns of Road Accidents Using Spatial Statistics (case study: Ilam Province, Iran) Accidents Using Spatial Statistics (case study). Transp. Res. Procedia 2017, 25, 2126-2138. [CrossRef]

58. Cobo, M.J.; Martínez, M.A.; Gutiérrez-salcedo, M.; Fujita, H.; Herrera-viedma, E. Knowledge-Based Systems 25 years at Knowledge-Based Systems: A bibliometric analysis. Knowl.-Based Syst. 2015, 80, 3-13. [CrossRef]

59. Dzikowski, P. A bibliometric analysis of born global firms. J. Bus. Res. 2018, 85, 281-294. [CrossRef]

60. Montalván-Burbano, N.; Pérez-Valls, M.; Plaza-Úbeda, J. innovation Analysis of scientific production on organizational innovation. Cogent Bus. Manag. 2020, 1975, 1-17. [CrossRef]

61. Bindra, S.; Parameswar, N.; Dhir, S. Strategic management: The evolution of the field. Strateg. Chang. 2019, 28, 469-478. [CrossRef]

62. Dhir, S.; Ongsakul, V.; Ahmed, Z.U.; Rajan, R. Integration of knowledge and enhancing competitiveness: A case of acquisition of Zain by Bharti Airtel. J. Bus. Res. 2020, 119, 674-684. [CrossRef]

63. Singh, S.; Dhir, S. Structured review using TCCM and bibliometric analysis of international cause-related marketing, social marketing, and innovation of the firm. Int. Rev. Public Nonprofit Mark. 2019, 16, 335-347. [CrossRef]

64. Singh, S.; Dhir, S.; Das, V.M.; Sharma, A. Bibliometric overview of the Technological Forecasting and Social Change journal: Analysis from 1970 to 2018. Technol. Forecast. Soc. Change 2020, 154, 119963. [CrossRef]

65. Pritchard, A. Statistical bibliography or bibliometrics. J. Doc. 1969, 25, 348-349.

66. Merigó, J.M.; Mulet-Forteza, C.; Valencia, C.; Lew, A.A. Twenty years of Tourism Geographies: A bibliometric overview. Tour. Geogr. 2019, 21, 881-910. [CrossRef] 
67. Oh, N.; Lee, J. Changing landscape of emergency management research: A systematic review with bibliometric analysis. Int. J. Disaster Risk Reduct. 2020, 49, 101658. [CrossRef]

68. Chen, C.; Hu, Z.; Liu, S.; Tseng, H. Emerging trends in regenerative medicine: A scientometric analysis in CiteSpace. Expert Opin. Biol. Ther. 2012, 12, 593-608. [CrossRef]

69. Katsanevakis, S.; Stelzenmüller, V.; South, A.; Sørensen, T.K.; Jones, P.J.S.; Kerr, S.; Badalamenti, F.; Anagnostou, C.; Breen, P.; Chust, G.; et al. Ecosystem-based marine spatial management: Review of concepts, policies, tools, and critical issues. Ocean Coast. Manag. 2011, 54, 807-820. [CrossRef]

70. Najjar, R.G.; Walker, H.A.; Anderson, P.J.; Barren, E.J.; Bord, R.J.; Gibson, J.R.; Kennedy, V.S.; Knight, C.G.; Megonigal, J.P.; O'Connor, R.E.; et al. The potential impacts of climate change on the mid-Atlantic coastal region. Clim. Res. 2000, 14, 219-233. [CrossRef]

71. Scott, D.; Simpson, M.C.; Sim, R. The vulnerability of Caribbean coastal tourism to scenarios of climate change related sea level rise. J. Sustain. Tour. 2012, 20, 883-898. [CrossRef]

72. Kildow, J.T.; McIlgorm, A. The importance of estimating the contribution of the oceans to national economies. Mar. Policy 2010 34, 367-374. [CrossRef]

73. Calgaro, E.; Lloyd, K. Sun, sea, sand and tsunami: Examining disaster vulnerability in the tourism community of Khao Lak, Thailand. Singap. J. Trop. Geogr. 2008, 29, 288-306. [CrossRef]

74. Larsen, R.K.; Calgaro, E.; Thomalla, F. Governing resilience building in Thailand's tourism-dependent coastal communities: Conceptualising stakeholder agency in social-ecological systems. Glob. Environ. Chang. 2011, 21, 481-491. [CrossRef]

75. Coombes, E.G.; Jones, A.P.; Sutherland, W.J.; Beach, W.P.; Coombes, E.G.; Jones, A.P.; Sutherland, W.J. The Implications of Climate Change on Coastal Visitor Numbers: A Regional Analysis The Implications of Climate Change on Coastal Visitor Numbers: A Regional Analysis. BioOne 2009, 25, 981-990. [CrossRef]

76. Student, J.; Kramer, M.R.; Steinmann, P. Annals of Tourism Research Simulating emerging coastal tourism vulnerabilities: An agent- based modelling approach. Ann. Tour. Res. 2020, 85, 103034. [CrossRef]

77. Buzinde, C.N.; Manuel-navarrete, D.; Kerstetter, D.; Redclift, M. Representations and adaptation to climate change. Ann. Tour. Res. 2010, 37, 581-603. [CrossRef]

78. Lou, W.; Qiu, J. Semantic information retrieval research based on co-occurrence analysis. Online Inf. Rev. 2014, 38, 4-23. [CrossRef]

79. Small, H. Co-citation in the scientific literature: A new measure of the relationship between two documents. J. Am. Soc. Inf. Sci. 1973, 24, 265-269. [CrossRef]

80. Amelung, B.; Viner, D.; Viner, D. Mediterranean Tourism: Exploring the Future with the Tourism Climatic Index Mediterranean Tourism: Exploring the Future with the Tourism Climatic Index. J. Sustain. Tour. 2006, 14, 349-366. [CrossRef]

81. Mieczkowski, Z. The tourism climatic index: A method of evaluating world. Can. Geogr. 1985, 29, 220-233. [CrossRef]

82. Kessler, M.M. Bibliographic Coupling between Scientific Papers. Am. Doc. 1963, 14, 123-131. [CrossRef]

83. Coombes, E.G.; Jones, A.P.; Bateman, I.J.; Tratalos, J.A.; Gill, J.A.; Showler, D.A.; Watkinson, A.R.; Sutherland, W.J. Spatial and temporal modeling of beach use: A case study of east Anglia, UK. Coast. Manag. 2008, 37, 37-41. [CrossRef] 